\title{
Fluid chemistry of the low temperature hyperalkaline hydrothermal system of Prony Bay (New Caledonia)
}

\author{
C. Monnin ${ }^{1}$, V. Chavagnac ${ }^{1}$, C. Boulart ${ }^{1, *}$, B. Ménez ${ }^{2}$, M. Gérard ${ }^{3}$, E. Gérard $^{2}$, C. Pisapia ${ }^{2}$, M. Quéméneur ${ }^{4}$, \\ G. Erauso $^{4}$, A. Postec ${ }^{4}$, L. Guentas-Dombrowski ${ }^{5,6}$, C. Payri ${ }^{5}$, and B. Pelletier ${ }^{7}$ \\ ${ }^{1}$ Géosciences Environnement Toulouse, Université de Toulouse/CNRS/IRD, 14, Avenue Edouard Belin, \\ 31400 Toulouse, France \\ ${ }^{2}$ Institut de Physique du Globe de Paris, Sorbonne Paris Cité, Université Paris Diderot, CNRS UMR7154, \\ 1 rue Jussieu, 75238 Paris CEDEX 5, France \\ ${ }^{3}$ Institut de minéralogie et de physique des milieux condensés, Université Pierre et Marie Curie - 4 place Jussieu, \\ 75005 Paris, France \\ ${ }^{4}$ Aix Marseille Université, CNRS/INSU, IRD, Mediterranean Institute of Oceanography (MIO), UM110, \\ 13288 Marseille, France \\ ${ }^{5}$ UR227 COREUS Ecosystèmes des communautés récifales et leurs usages dans le Pacifique, \\ Centre IRD de Nouméa, BP A5, 98848 Nouméa, New Caledonia \\ ${ }^{6}$ Toulon Université, Laboratoire des Matériaux Polymères Interfaces Environnement Marin (MAPIEM), \\ ISITV - Avenue Georges Pompidou BP56 - 83162 La Valette-du-Var CEDEX, France \\ ${ }^{7}$ Grand Observatoire de l'environnement et de la biodiversité terrestre et marine du Pacifique Sud (GIS GOPS), \\ Centre IRD de Nouméa, BP A5, 98848 Nouméa, New Caledonia \\ *now at: Centre IFREMER Brest, Géosciences Marines, Laboratoire Géochimie Métallogénie, B.P. 70, \\ 29280 Plouzané France
}

Correspondence to: C. Monnin (christophe.monnin@get.obs-mip.fr)

Received: 26 February 2014 - Published in Biogeosciences Discuss.: 29 April 2014

Revised: 31 July 2014 - Accepted: 9 September 2014 - Published: 16 October 2014

\begin{abstract}
The terrestrial hyperalkaline springs of Prony Bay (southern lagoon, New Caledonia) have been known since the nineteenth century, but a recent high-resolution bathymetric survey of the seafloor has revealed the existence of numerous submarine structures similar to the well-known Aiguille de Prony, which are also the location of high-pH fluid discharge into the lagoon. During the HYDROPRONY cruise (28 October to 13 November 2011), samples of waters, gases and concretions were collected by scuba divers at underwater vents. Four of these sampling sites are located in Prony Bay at depths up to $50 \mathrm{~m}$. One (Bain des Japonais spring) is also in Prony Bay but uncovered at low tide and another (Rivière des Kaoris spring) is on land slightly above the seawater level at high tide. We report the chemical composition ( $\mathrm{Na}, \mathrm{K}, \mathrm{Ca}, \mathrm{Mg}, \mathrm{Cl}, \mathrm{SO}_{4}$, dissolved inorganic carbon, $\mathrm{SiO}_{2}(\mathrm{aq})$ ) of 45 water samples collected at six sites of high-pH water discharge, as well as the composition of gases.
\end{abstract}

Temperatures reach $37^{\circ} \mathrm{C}$ at the Bain des Japonais and $32^{\circ} \mathrm{C}$ at the spring of the Kaoris. Gas bubbling was observed only at these two springs. The emitted gases contain between 12 and $30 \%$ of hydrogen in volume of dry gas, 6 to $14 \%$ of methane, and 56 to $72 \%$ of nitrogen, with trace amounts of carbon dioxide, ethane and propane.

$\mathrm{pH}$ values and salinities of all the 45 collected water samples range from the seawater values $\left(8.2\right.$ and $\left.35 \mathrm{~g} \mathrm{~L}^{-1}\right)$ to hyperalkaline freshwaters of the $\mathrm{Ca}-\mathrm{OH}$ type $(\mathrm{pH} 11$ and salinities as low as $0.3 \mathrm{~g} \mathrm{~L}^{-1}$ ) showing that the collected samples are always a mixture of a hyperalkaline fluid of meteoric origin and ambient seawater. Cl-normalized concentrations of dissolved major elements first show that the Bain des Japonais is distinct from the other sites. Water collected at this site are three component mixtures involving the high$\mathrm{pH}$ fluid, the lagoon seawater and the river water from the nearby Rivière du Carénage. The chemical compositions of 
the hyperalkaline endmembers (at $\mathrm{pH} 11$ ) are not significantly different from one site to the other although the sites are several kilometres away from each other and are located on different ultramafic substrata. The very low salinity of the hyperalkaline endmembers shows that seawater does not percolate through the ultramafic formation.

Mixing of the hyperalkaline hydrothermal endmember with local seawater produces large ranges and very sharp gradients of $\mathrm{pH}$, salinity and dissolved element concentrations. There is a major change in the composition of the water samples at a $\mathrm{pH}$ around 10, which delimitates the marine environment from the hyperalkaline environment. The redox potential evolves toward negative values at high $\mathrm{pH}$ indicative of the reducing conditions due to bubbling of the $\mathrm{H}_{2}$-rich gas. The calculation of the mineral saturation states carried out for the $\mathrm{Na}-\mathrm{K}-\mathrm{Ca}-\mathrm{Mg}-\mathrm{Cl}-\mathrm{SO}_{4}-\mathrm{DIC}-\mathrm{SiO}_{2}-\mathrm{H} 2 \mathrm{O}$ system shows that this change is due to the onset of brucite formation. While the saturation state of the $\mathrm{Ca}$ carbonates over the whole $\mathrm{pH}$ range is typical of that found in a normal marine environment, $\mathrm{Mg}$ and $\mathrm{Mg}$-Ca carbonates (magnesite, hydromagnesite, huntite, dolomite) exhibit very large supersaturations with maximum values at a $\mathrm{pH}$ of around 10, very well marked for the Bain des Japonais, emphasizing the role of water mixing in mineral formation.

The discharge of high-pH waters of meteoric origin into the lagoon marine environment makes the hydrothermal system of Prony Bay unique compared to other low temperature serpentinizing environments such as Oman (fully continental) or Lost City (fully marine).

\section{Introduction}

In 2000, the discovery of the submerged Lost City hydrothermal field (LCHF) along the mid-Atlantic ridge has focused attention on the role of ultramafic rock alteration (i.e. serpentinization) in the global geochemical cycles of carbon and hydrogen as well as in producing favorable environmental conditions for the synthesis of prebiotic molecules (FruhGreen et al., 2003; Kelley et al., 2001; Kelley et al., 2005). At Lost City, the fluids produced by the serpentinization process are characterized by high $\mathrm{pH}(9-11)$ and moderate temperatures $\left(40-90^{\circ} \mathrm{C}\right)$ and are enriched in calcium, methane and hydrogen compared to background seawater (Kelley et al., 2005). The highly reducing conditions of the serpentinizing environment allows the development of abiotic organic compounds (Lang et al., 2010) and hosts a large and specific community of microorganisms (Brazelton et al., 2010, 2006). Such hyperalkaline hydrothermal systems may have been numerous on the early Earth, as well as on the Martian surface (Szponar et al., 2012) and may have also been the locus of the emergence of earliest forms of life (Muntener, 2010; Russell, 2007; Russell et al., 2010).
Although the Lost City site focused the attention of the scientific community, low-temperature, high-pH hydrothermal systems have been previously reported on land in ophiolites at several locations over the world, such as in Oman (Barnes and O'Neil, 1969; Chavagnac et al., 2013b; Neal and Stanger, 1984b; Stanger, 1985), in Bosnia (Barnes et al., 1978), in northern Italy, Ligurian Alps, (Chavagnac et al., 2013b; Cipolli et al., 2004), in New Caledonia (Launay and Fontes, 1985), and more recently in Ontario (Sader et al., 2007), in Newfoundland (Szponar et al., 2012) and in California (Morrill et al., 2013). In ophiolites, hyperalkaline fluids derived from freshwater have low salinity and can mix with close-to-neutral continental runoff waters. In the marine environment, other than the Lost City site, high-pH fluids are found at the mud volcanoes of the Mariana forearc where they ascend from the serpentinites of the subducting plate (Mottl, 2009; Mottl et al., 2004). Lost City and Mariana forearc hyperalkaline fluids have salinities close to that of seawater and mix with deep seawater at the vents. Such hyperalkaline systems can therefore be characterized by the type of environment in which these peculiar high-pH fluids discharge and the type of local waters with which they can mix (Table 1).

The Prony hydrothermal field (PHF) appears quite unique as low-salinity, high-pH waters discharge into a coastal marine environment, the New Caledonia southern lagoon. The terrestrial alkaline springs of Prony Bay have been known since the nineteenth century (Garnier, 1871). A recent highresolution bathymetric survey of the seafloor has revealed the existence of numerous submarine structures similar to the well-known Aiguille de Prony, which are also the location of high-pH fluid discharge into the lagoon (Pelletier et al., 2006).

During the HYDROPRONY cruise (28 October to 13 November 2011) samples of water, gases and concretions forming at the high-pH fluid outlets were collected by the scientific team with the help of scuba divers. We here report the chemical composition of 45 water samples collected at six sites of high-pH water discharge. Four of these sampling sites are located offshore in Prony Bay at water depths up to $50 \mathrm{~m}$ (ST07, ST09, ST11 and ST12), one (Bain des Japonais, noted below as BdJ spring) is also in Prony Bay but uncovered at low tide and one, set up as a spa by the local touristic administration (Rivière des Kaoris, shortened below as Kaoris spring), is on land slightly above the seawater level at high tide. Furthermore, we present the chemical composition of gases emitted at these last two sites. No such gas bubbling has been observed at the deeper offshore sites (namely ST07, ST09, site ST11 and ST12). These data show that mixing of the alkaline hydrothermal endmember with local seawater produces large ranges and very sharp gradients of $\mathrm{pH}$, salinity and dissolved element concentrations. We then calculated the mineral saturation indices to investigate the conditions of the formation of brucite and $\mathrm{Mg}$-Ca carbonates in this peculiar environment. 
Table 1. High-pH waters worldwide. The first column (marine or continental) is the general geological environment in which the springs are found. "Input water" is the type of water entering the local hydrologic cycle. The "discharge environment" is the location of the springs, on continental surfaces or in the deep or shallow marine environment. "Local waters" are the waters that are found in the type of geological environment (for example formation waters of continental kimberlites or river waters on continental surface) that mix with the high-pH waters at some point of the hydrologic pathways.

\begin{tabular}{|c|c|c|c|c|c|c|c|}
\hline & Input water & $\begin{array}{l}\text { Discharge } \\
\text { environment }\end{array}$ & Location & $\begin{array}{l}\text { Geological } \\
\text { environment }\end{array}$ & Highest $\mathrm{pH}$ & Local waters & Reference \\
\hline \multirow{10}{*}{ 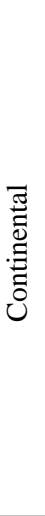 } & \multirow{10}{*}{$\begin{array}{l}\text { meteoric } \\
\text { (river) }\end{array}$} & \multirow[t]{10}{*}{ continental } & Ontario & continental & 12.5 & formation & Sader et al. (2007) \\
\hline & & & Oman & $\begin{array}{l}\text { kimberlites } \\
\text { ophiolite }\end{array}$ & 12.2 & $\begin{array}{l}\text { porewaters } \\
\text { continental runoff }\end{array}$ & $\begin{array}{l}\text { Chavagnac et al. (2013); } \\
\text { Neal and Stanger (1984) }\end{array}$ \\
\hline & & & Portugal & ophiolite & 10.9 & continental runoff & Marques et al. (2008) \\
\hline & & & Philippines & ophiolite & 11.7 & continental runoff & Fujii et al. (2010) \\
\hline & & & Northern Italy & ophiolite & 11.9 & continental runoff & Cipolli et al. (2004); \\
\hline & & & & & & & $\begin{array}{l}\text { Boschetti and Toscani (2008), } \\
\text { Chavagnac et al. (2013) }\end{array}$ \\
\hline & & & Cyprus & ophiolite & 11.6 & continental runoff & Neal and Shand (2002) \\
\hline & & & The Cedars & ophiolite & 11.9 & continental & Morrill et al. (2013) \\
\hline & & & (California) & & & $\begin{array}{l}\text { runoff/formation } \\
\text { porewaters }\end{array}$ & \\
\hline & & & Newfoundland & ophiolite & 12.3 & continental runoff & Szponar et al. (2012) \\
\hline \multirow[b]{2}{*}{ 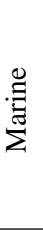 } & \multirow[t]{2}{*}{$\begin{array}{l}\text { marine } \\
\text { (seawater) }\end{array}$} & \multirow[t]{2}{*}{$\begin{array}{l}\text { marine } \\
\text { (deep) }\end{array}$} & $\begin{array}{l}\text { Lost City (mid } \\
\text { Atlantic Ridge) }\end{array}$ & & 11.0 & $\begin{array}{l}\text { ocean bottom } \\
\text { seawater }\end{array}$ & Kelley et al. (2005) \\
\hline & & & $\begin{array}{l}\text { Mariana } \\
\text { forearc } \\
\text { (southwest } \\
\text { Pacific) }\end{array}$ & $\begin{array}{l}\text { marine sediments/ } \\
\text { mud volcanoes }\end{array}$ & 12.5 & $\begin{array}{l}\text { marine sediment } \\
\text { porewaters }\end{array}$ & Mottl et al. (2004) \\
\hline 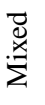 & $\begin{array}{l}\text { meteoric } \\
\text { (river) }\end{array}$ & $\begin{array}{l}\text { marine } \\
\text { (shallow) }\end{array}$ & $\begin{array}{l}\text { Bain de Prony } \\
\text { (New } \\
\text { Caledonia) }\end{array}$ & ophiolite & 11.2 & lagoon seawater & $\begin{array}{l}\text { Launay and Fontes (1985); } \\
\text { this work }\end{array}$ \\
\hline
\end{tabular}

\section{Geological setting of the Prony hydrothermal field}

The New Caledonia islands group is located on the eastern margin of the Australian plate on the western side of the Vanuatu subduction zone. The NW-SE elongated main island represents the emerged portion of the New Caledonia ridge and includes a large allochthonous sheet of oceanic lithosphere thrusted over continental basement at the late Eocene (Avias, 1967; Cluzel et al., 2001; Pirard et al., 2013). The $3.5 \mathrm{~km}$ thick ophiolite nappe covers an area of $7000 \mathrm{~km}^{2}$ distributed throughout the island, the main part covering the southern end of the main island. It is composed of harzburgite in which numerous intercalations of dunites and pyroxenites are capped by gabbroic rocks (Guillon, 1975; Pirard et al., 2013). The lithological evolution from dunites to gabbros is marked by an enrichment in aluminium, calcium and alkali (Guillon, 1975). Seismic reflexion and bathymetry show that the topography of the terminations and the borders of the island are controlled by major normal faults (Chardon et al., 2008; Chardon and Chevillotte, 2006; Collot et al., 1982; Flamand, 2006). The association of large low angle detachment faults and high angle conjugate normal faults leads to a general thinning of the ultramafic nappe during its post-obduction evolution (Chardon and Chevillotte, 2006;
Lagabrielle and Chauvet, 2008; Lagabrielle et al., 2005). In their recent petrological study of the Massif du Sud, Pirard et al. (2013) indicate that the ophiolite reaches a thickness between 1000 and $4000 \mathrm{~m}$. The intensity of tectonic deformation allows fluid transfer from the surface down to the ultramafic nappe, as evidenced by a thick $(1-300 \mathrm{~m})$ zone of sheared serpentinite (Guillon, 1975) as well as centimetrethick silica infills bearing vertical striae along the faults zone (Lagabrielle and Chauvet, 2008). Fluid circulation within the mantle peridotite induces the formation of hyperalkaline hydrothermal fluids produced by serpentinization reactions (Pelletier et al., 2006).

These obducted ultramafic rocks are exposed to an intense weathering under a tropical climate. A large part of New Caledonia's main island ("Grande Terre", nicknamed "Le caillou") is covered by a thick lateritic alteration layer with an enrichment at its base in nickel and cobalt that are mined and treated by local metallurgical plants (Bonvallot et al., 2012; Quesnel et al., 2013).

Hydrothermal springs were observed at the mouth of the Rivière des Kaoris and at the Baie du Carénage (the latter also named "Bain des Japonais") as early as the end of nineteenth century (Garnier, 1871). Also in the middle of Prony 
Bay, a high carbonated pinnacle towering $35 \mathrm{~m}$ above the seafloor up to $2 \mathrm{~m}$ below the water surface, called "Roc Aiguille" or Aiguille de Prony, has been known for a long time as a navigation hazard. It is the location of springs well known to scuba divers (Launay and Fontes, 1985; Magnier, 1979). During scientific cruises on the R/V Alis in 2004 and 2005, multi-beam bathymetric map and scuba dives revealed that the bottom of Prony Bay is the location of several two to ten metre high domes and pinnacles, besides the Aiguille de Prony, at water depths between 30 and $50 \mathrm{~m}$, sometimes located on $200 \mathrm{~m}$ wide and few metres deep circular depressions, with hydrothermal chimneys at their centres (Pelletier and Chevillon, 2006; Pelletier et al., 2006). These formations, which looked anomalous with regard to the general topography of the lagoon floor, are generally composed of a main whitish chimney towering several metres above the seafloor surrounded by additional peripheral smaller chimneys or pinnacles.

\section{Sampling locations, procedures and analytical methods}

\subsection{Sampling locations}

During the HYDROPRONY cruise, which took place on the R/V Alis from 28 October till 13 November 2011, fluid samples and chimney sections were collected on land and at sea by divers at the underwater sites. The sampling locations of the HYDROPRONY cruise are of three types: one single site on land - the Kaoris spring, one site uncovered at low tide the BdJ spring, and four underwater sites named "deep sites" (ST07, ST09, ST011 and ST12) (Fig. 1). The geological map (Fig. 1; Maurizot and Vendé-Leclerc, 2009) indicates that the eastern side of Prony Bay is composed of gabbros and peridotites (with no indication of their degree of serpentinization) and the western side of serpentinites, so that there must be a transition between the two types of rocks under water in Prony Bay. The sites ST09 and ST11, as well as the BdJ spring, seem to be located on a serpentinized substratum, while the sites ST07 and ST12 are closer to the serpentinites. The Kaoris spring is located at the transition between the peridotites and the serpentinites. To date, it is nevertheless impossible to have a better idea of the nature of the substratum at the HYDROPRONY sampling sites.

The Kaoris spring is situated above the sea level at the eastern end of Baie du Carénage (Fig. 1). It has been channeled by the Caledonian touristic administration into a small pool (about $2 \mathrm{~m}$ by $3 \mathrm{~m}, 1.5 \mathrm{~m}$ deep), the water discharge being located on one side at the bottom of this pool.

The Bain des Japonais spring is located in the western branch of the Baie du Carénage close to the mouth of a small creek (Rivière du Carénage). There, many vents discharging fluids and gas bubbles can be found on and around these platforms that are uncovered at low tide (Fig. 2). On one of them a small bath presently made out of bricks has been built by the convicts ("bagnards" in French) at the end of the nineteenth century for the use of the administrators of the nearby Prony penitentiary. It has been later named Bain des Japonais (bath of the Japanese) due to its use by the Japanese workers in the neighbouring mining camps. This bath is usually filled by a hose plugged into one of the vents, but it was empty in November 2011 and no water was flowing out of this hose, despite many active vents around the platform. It has been observed that water flows out of this hose at high tide. The tidal range in Prony Bay is about $1 \mathrm{~m}$. It is sufficient to build up the pressure and make the water flow out of the hose at high tide. A series of samples has been taken at one of the underwater vents located about $10 \mathrm{~cm}$ below the surface at low tide on the side of the main platform, the first sample by inserting the plastic syringe directly into the vent, and the following samples at increasing distances from the vent in order to collect fluids in the whole dilution range from the high-pH endmember to the normal seawater of the Baie du Carénage. The flow rate is so small that at $30 \mathrm{~cm}$ away from the vent orifice, $\mathrm{pH}$ and temperature have the values of the lagoon seawater, free of any discharge. This small plume is nevertheless large enough to allow measurements (such as the in situ pH-redox potential, see below) and sampling to be carried out over the whole $\mathrm{pH}$ range.

Before the cruises on the R/V Alis in 2005 (Pelletier and Chevillon, 2006; Pelletier et al., 2006), the only known submarine edifice was the pinnacle located in the middle of Prony Bay (Aiguille de Prony, Site ST07). It was previously described as a coral formation before its hydrothermal origin was established (Launay and Fontes, 1985; Magnier, 1979). Scuba divers commonly describe the discharge of shimmering fluids and gas bubbles all around the pinnacle, that can be virtually "lit up as candlelight" but this activity has changed over the years. During the dives of the HYDROPRONY cruise, the activity was apparently at a minimum, with very limited fluid discharge and no gas bubbles. Four of the underwater structures revealed by the high-resolution bathymetric survey of Prony Bay during the 2005 R/V Alis cruise (Pelletier et al., 2006) were selected as fluid sampling sites (Fig. 1). These sites (ST07, ST09, ST011 and ST12) are the location of active springs and hydrothermal concretions at depths between 20 and $50 \mathrm{~m}$ below sea level.

\subsection{Sampling procedures, in situ measurements and analytical methods}

The fluids were collected either with gas-tight $200 \mathrm{~mL}$ titanium bottles (http://wwz.ifremer.fr/deep/Instrumentation/ Outils-de-mesure-grand-fond) or with sterile $60 \mathrm{~mL}$ polypropylene syringes equipped with a $\sim 15 \mathrm{~cm}$ hose that was introduced into the vents. $\mathrm{pH}$ was measured directly at the vents when accessible or immediately after recovery when the fluids were collected at depth. Fluids were filtered using a mixed esters of cellulose membrane (Millex-HA), 


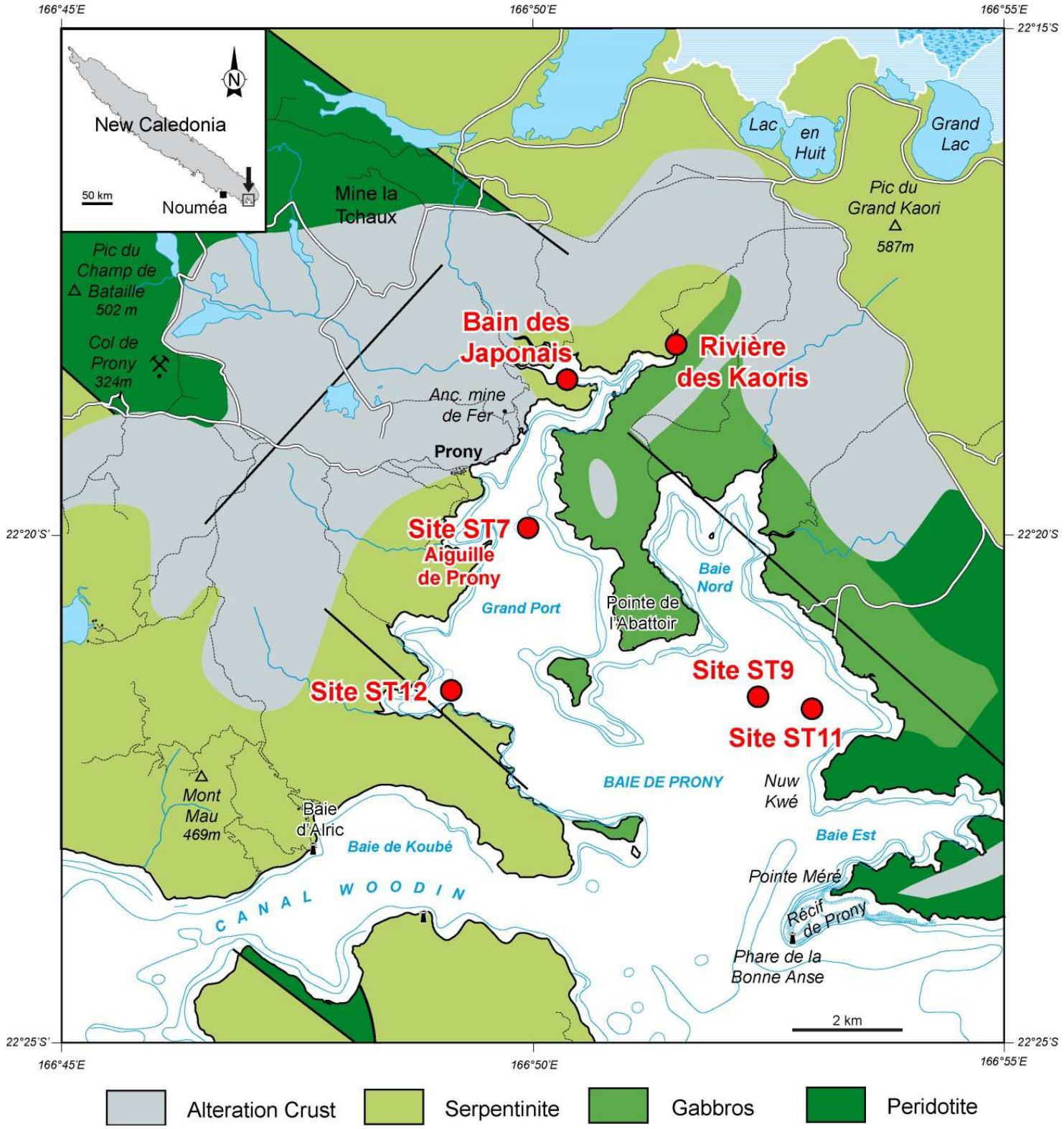

Figure 1. Simplified geological map of Prony Bay (from Maurizot and Vendé-Leclerc, 2009) with the location of the sampling sites.

which removes microorganisms, particles, precipitates, and suspended material larger than $0.45 \mu \mathrm{m}$, before storage in low-density polyethylene bottles for chemical analyses on shore at the Laboratoire Géosciences Environnement Toulouse (GET, France). All fluid samples were clear, free of visible particles. They had not been acidified before storage. Gas was emitted at an almost continuous flow of millimetric to centrimetric bubbles at BdJ and Kaoris springs (Fig. 2). All gas samples were collected into crimp-sealed gas glass bottles by water displacement.

Major and minor element concentrations were measured on all collected samples. $\mathrm{Si}, \mathrm{Mg}, \mathrm{Ca}, \mathrm{Na}$ and $\mathrm{K}$ concentrations were measured by inductively coupled plasma optical emission spectrometry (ICP-OES; Horiba Jobin Yvon Ultima 2). The instrument was calibrated using synthetic standards and/or IAPSO Standard Seawater (OSIL Limited, UK) and achieved a precision of $2 \%$ or better. The analytical and instrumental procedure used for the analyses of deep site fluids is described in detail by Besson et al. (in press). The full set of standards was run before and after each group of analyses to check the performance of the instrument. In addition, one standard was run as a sample before, during and after each group of analyses, to assess the instrument drift through the course of the analyses. All the concentrations reported in Table 2 are, therefore, drift and blank corrected. Anion concentrations $\left(\mathrm{Cl}, \mathrm{SO}_{4}\right)$ were measured by ion chromatography 


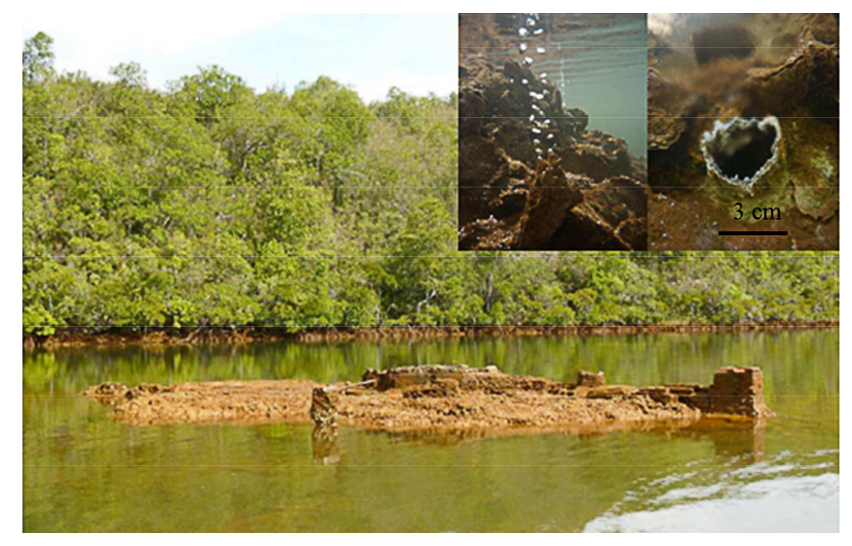

Figure 2. The Bain des Japonais spring (abbreviated as BdJ spring in the text). The carbonate platform is uncovered at low tide. It is surrounded by several underwater vents discharging high-pH waters and gas bubbles. Note the brick walls built by the convicts of the Prony penitentiary in the nineteenth century.

(IC, Dionex ICS 2000), which was similarly calibrated using IAPSO seawater as a standard at various dilution factors. Dissolved inorganic carbon was measured using a Shimadzu TOC-VCSN instrument.

Gases from the samples collected in the $10 \mathrm{ml}$ glass vials were transferred into a pre-evacuated, pressure-gauged sample loop. This allows for the determination of the total pressure of the gas samples. All gases were then analysed using a Hewlett Packard 7890A gas chromatograph fitted with HP QPlot columns and micro-catharometer (TCD) associated with a flame ionization detector (FID). Mass balance of quantified gases matches the global gas pressure of the samples.

\section{Temperatures, gas and water compositions}

\subsection{Temperature}

The Grand Observatoire du Pacifique Sud (GOPS) maintains a network of temperature sensors that record the temperature of the lagoon water (http://www.observatoire-gops.org/ fr/temperatures-cotieres). The yearly variation of the surface temperature is between 22 and $28^{\circ} \mathrm{C}$. The surface temperature of the lagoon water at the time of the HYDROPRONY cruise measured with a CTD probe was $24.4^{\circ} \mathrm{C}$, while it was $23.3^{\circ} \mathrm{C}$ at the lagoon floor (around $45 \mathrm{~m}$ ). The temperature of the venting fluids has been measured only at two sites: Bain des Japonais and Rivière des Kaoris (Table 2; Fig. 3). The highest temperature value at the time of the HYDROPRONY cruise was $37.6^{\circ} \mathrm{C}$ measured at the $\mathrm{BdJ}$ spring. There is a linear correlation between temperature and $\mathrm{pH}$ measured at the vents of the BdJ spring as a result of the dilution of the hydrothermal alkaline fluid by the lagoon seawater. Note that

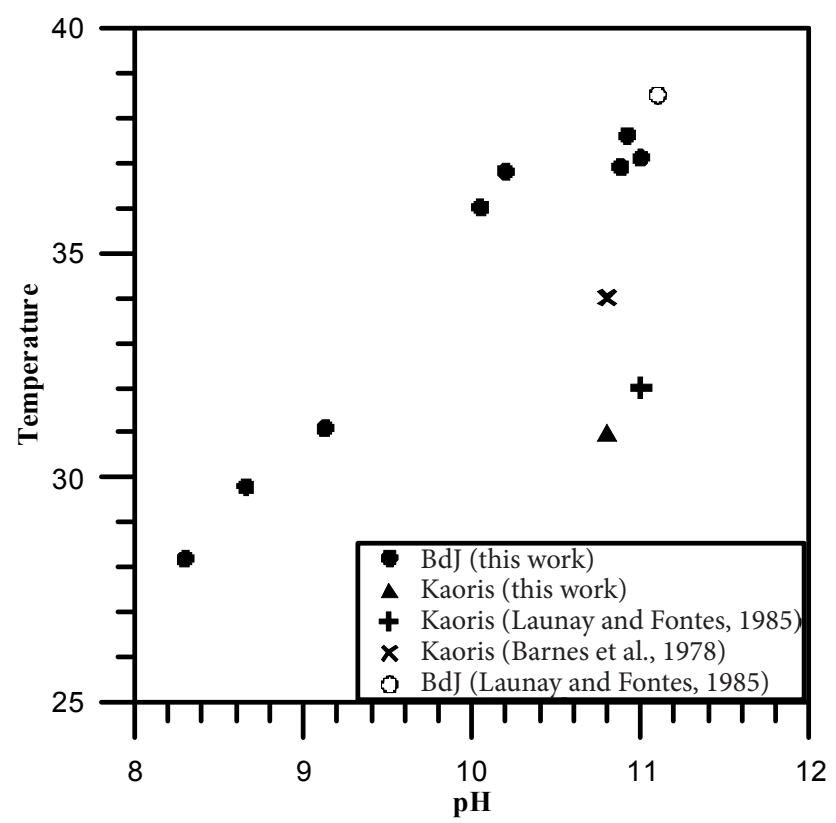

Figure 3. In situ temperature of Prony Bay water samples versus $\mathrm{pH}$.

the temperature levels off for the highest $\mathrm{pH}$ values at the BdJ spring (Fig. 3).

Garnier (1871) measured a temperature of $33^{\circ} \mathrm{C}$ for the spring waters (probably those of the $\mathrm{BdJ}$ and the Kaoris springs) during his journey to New Caledonia at the end of the nineteenth century. A few temperature values have been reported by various authors over the last few decades, such as (Cox et al., 1982) who noted $40^{\circ} \mathrm{C}$ at BdJ. The temperature measured at the surface of the pool at the Kaoris spring on 30 October 2011 was $31^{\circ} \mathrm{C}$. Launay and Fontes (1985) and Cox et al. (1982) reported $32^{\circ} \mathrm{C}$ at this location, while Barnes et al. (1978) reported $34^{\circ} \mathrm{C}$ (compiled in Fig. 3). The dates of the measurements are not given by these authors. During the fall of 2012, we installed temperature recorders at various alkaline vents in Prony Bay in order to monitor the dynamics of the hydrothermal system. The first observations show a very stable temperature of the on land Kaoris spring at $32^{\circ} \mathrm{C}$, and a seasonal variation of the temperatures recorded at the $\mathrm{BdJ}$ spring and at the Aiguille de Prony (ST07). This seasonal variation is correlated with that of the temperature of the lagoon water to which the temperature recorders are sensitive due to their emplacement (Monnin et al., 2013).

\subsection{Gas composition}

Gas bubbles were observed only at the BdJ and the Kaoris springs at the time of the HYDROPRONY cruise. We analysed 18 samples for the BdJ spring and 11 samples for the Kaoris spring collected over a period of several months during the survey of the springs (Monnin et al., 2013). No change of the gas composition during this time interval has 
Table 2. Major and minor elemental composition and temperature of the waters collected in Prony Bay during the HYDROPRONY cruise (b.d.l.: below detection level; DIC: dissolved inorganic carbon).

\begin{tabular}{|c|c|c|c|c|c|c|c|c|c|c|c|c|}
\hline Site & $\begin{array}{l}\text { Sample } \\
\text { name }\end{array}$ & $\mathrm{pH}$ & $T^{\circ} \mathrm{C}$ & $\begin{array}{r}\mathrm{Si} \\
\mathrm{mmol} \mathrm{L}^{-1}\end{array}$ & $\begin{array}{r}\text { DIC } \\
\mathrm{mmolL}^{-1}\end{array}$ & $\begin{array}{r}\mathrm{Mg} \\
\mathrm{mmol} \mathrm{L}^{-1}\end{array}$ & $\begin{array}{r}\mathrm{Ca} \\
\mathrm{mmol} \mathrm{L}^{-1}\end{array}$ & $\mathrm{mmol} \mathrm{L}^{-1}$ & $\mathrm{mmol} \mathrm{L}^{-1}$ & $\mathrm{mmol} \mathrm{L}^{-1}$ & $\mathrm{mmol} \mathrm{L}^{-1}$ & $\begin{array}{r}\mathrm{SO}_{4} \\
\mathrm{mmol} \mathrm{L}^{-1}\end{array}$ \\
\hline $\begin{array}{l}\text { Standard } \\
\text { seawater } \\
\text { (Millero, } \\
\text { 2006) }\end{array}$ & & & & & 2.07 & 54.10 & 10.53 & 480.47 & 10.46 & & 559.14 & 28.93 \\
\hline \multirow{14}{*}{$\begin{array}{l}\text { Bain des } \\
\text { Japonais }\end{array}$} & HP11-BdJ-Ilot1-W1C & 11.08 & & 0.0009 & 0.3921 & 0.006 & 0.518 & 2.38 & 0.32 & 0.0071 & 2.22 & 0.10 \\
\hline & HP11-BdJ-Ilot1-W2 & 10.48 & & 0.0028 & 0.3573 & 0.198 & 0.525 & 7.29 & 0.42 & 0.0055 & 5.47 & 0.28 \\
\hline & HP11-BdJ-Ilot1-W3 & 10.01 & & 0.0102 & 0.4737 & 2.344 & 0.957 & 26.14 & 0.81 & 0.0059 & 21.61 & 1.24 \\
\hline & HP11-BdJ-Ilot1-W5 & 11.07 & & 0.0025 & 0.4601 & b.d.l. & 0.444 & 1.28 & 0.30 & 0.0055 & 0.41 & 0.01 \\
\hline & HP11-BdJ-Ilot1-W6 & 10.68 & & 0.0059 & 0.3616 & 0.092 & 0.667 & 5.68 & 0.41 & 0.0061 & 4.02 & 0.19 \\
\hline & HP11-BdJ-Ilot2-W1 & 10.87 & & b.d.1. & 0.4096 & 0.029 & 0.594 & 2.98 & 0.36 & 0.0069 & 1.84 & 0.07 \\
\hline & HP11-BdJ-Dil1 & 10.05 & 36.0 & 0.0073 & 0.4599 & 3.98 & 1.29 & 22.63 & 1.54 & 0.0053 & 52.67 & 3.36 \\
\hline & HP11-BdJ-Dil2 & 9.13 & 31.1 & 0.0432 & 1.2946 & 23.83 & 5.00 & 197.98 & 4.75 & 0.0064 & 179.27 & 11.85 \\
\hline & HP11-BdJ-Dil3 & 8.66 & 29.8 & 0.0498 & 1.6152 & 33.58 & 6.87 & 284.15 & 6.36 & 0.0204 & 241.80 & 16.09 \\
\hline & HP11-BdJ-Dil4 & 10.20 & 36.8 & 0.0052 & 0.4774 & 1.34 & 0.97 & 1.91 & 1.15 & 0.0055 & 34.52 & 2.16 \\
\hline & HP11-BdJ-Dil5 & 8.30 & 28.2 & 0.0316 & 1.7884 & 45.16 & 9.16 & 392.81 & 8.52 & 0.0257 & 322.05 & 21.45 \\
\hline & HP11-BdJ-Dil6 & 11.00 & 37.1 & 0.0039 & b.d.l. & 0.028 & 0.21 & 2.55 & 0.43 & 0.0269 & 1.44 & 0.06 \\
\hline & HP11-BdJ-Dil7 & 10.92 & 37.6 & 0.0029 & 0.3097 & 0.024 & 0.22 & 1.65 & 0.39 & 0.0109 & 0.66 & 0.02 \\
\hline & HP11-BdJ-Dil8 & 10.88 & 36.9 & 0.0025 & 0.3996 & 0.036 & 0.41 & 1.75 & 0.40 & 0.0064 & 0.76 & 0.02 \\
\hline \multirow{2}{*}{$\begin{array}{l}\text { Rivière } \\
\text { des Kaoris }\end{array}$} & HP11-CarKao-W1 & 10.80 & 31.0 & 0.0662 & 0.1440 & b.d.l. & 0.36 & 0.65 & 0.08 & 0.0032 & 0.23 & b.d.l. \\
\hline & HP11-CarKao-W2 & 10.80 & 31.0 & 0.0656 & 0.0000 & b.d.l. & 0.38 & 0.58 & 0.08 & 0.0025 & 0.19 & b.d.l. \\
\hline \multirow[t]{5}{*}{ Site ST11 } & HP11-Site11-W1 & 10.64 & & 0.0502 & 0.5376 & 2.516 & 2.28 & 40.52 & 0.00 & & 45.78 & 1.54 \\
\hline & HP11-Site11-W4 & 9.58 & & 0.0394 & 1.1156 & 31.69 & 7.28 & 270.85 & 5.09 & & 327.74 & 16.16 \\
\hline & HP11-Site11-W5 & 8.76 & & 0.0116 & 1.8450 & 45.44 & 9.45 & 386.58 & 7.36 & & 451.96 & 22.56 \\
\hline & HP11-Site11-W10 & 9.06 & & 0.0344 & 1.5244 & 31.37 & 7.19 & 263.71 & 4.87 & & 319.18 & 15.79 \\
\hline & HP11-Site11-W11 & 9.38 & & 0.0432 & 1.2131 & 22.75 & 6.31 & 199.40 & 3.69 & & 248.69 & 12.13 \\
\hline \multirow[t]{7}{*}{ Site ST12 } & HP11-Site12-W1 & 11.00 & & 0.0298 & 0.3824 & b.d.l. & 0.55 & 40.05 & 0.14 & & 41.74 & 0.38 \\
\hline & HP11-Site12-W3 & 8.92 & & 0.0249 & 1.3080 & 44.02 & 8.27 & 384.52 & 7.56 & & 432.70 & 21.50 \\
\hline & HP11-Site12-W4 & 9.50 & & 0.0207 & 0.6818 & 22.18 & 4.43 & 191.24 & 3.91 & & 247.31 & 11.53 \\
\hline & HP11-Site12-W5 & 8.85 & & 0.0121 & 1.6377 & 45.18 & 8.69 & 385.32 & 7.49 & & 440.03 & 21.79 \\
\hline & HP11-Site12-W6 & 9.34 & & 0.0158 & 0.9075 & 37.44 & 6.32 & 323.69 & 6.47 & & 371.92 & 18.20 \\
\hline & HP11-Site12-W7 & 8.60 & & 0.0108 & 1.8849 & 45.34 & 8.90 & 393.22 & 7.79 & & 447.21 & 22.17 \\
\hline & HP11-Site12-W8 & 8.15 & & 0.0077 & 0.4070 & 54.65 & 10.28 & 475.50 & 9.28 & & 515.39 & 25.89 \\
\hline \multirow[t]{12}{*}{ Site ST7 } & HP11-Site7-W1 & 9.73 & & b.d.l. & 0.5830 & 23.32 & 4.91 & 190.96 & 3.69 & & 252.37 & 12.24 \\
\hline & HP11-Site7-W2 & 9.66 & & b.d.l. & 0.6666 & 22.92 & 4.96 & 187.73 & 3.62 & & 250.44 & 12.14 \\
\hline & HP11-Site7-W3 & 9.67 & & b.d.l. & 0.6721 & 18.69 & 4.43 & 154.31 & 2.93 & & 212.43 & 10.17 \\
\hline & HP11-Site7-W4 & 9.61 & & b.d.l. & 0.6342 & 20.42 & 4.59 & 167.61 & 3.40 & & 225.87 & 10.82 \\
\hline & HP11-Site7-W5 & 9.72 & & b.d.l. & 0.7691 & 24.43 & 5.17 & 198.08 & 3.74 & & 262.81 & 12.78 \\
\hline & HP11-Site7-W6 & 9.61 & & b.d.l. & 0.7067 & 28.73 & 5.74 & 235.44 & 4.53 & & 297.38 & 14.59 \\
\hline & HP11-Site7-W3Ti & 9.44 & & 0.0138 & 0.6870 & 41.14 & 7.16 & 346.46 & 7.33 & & 400.87 & 19.95 \\
\hline & HP11-Site7-W7 & 10.00 & & 0.0001 & 0.5377 & 27.95 & 5.46 & 232.61 & 4.81 & & 290.68 & 14.20 \\
\hline & HP11-Site7-W8 & 10.13 & & b.d.l. & 0.4945 & 20.08 & 4.41 & 163.75 & 3.32 & & 223.03 & 10.64 \\
\hline & HP11-Site7-W9 & 9.91 & & 0.0006 & 0.4971 & 29.36 & 5.76 & 249.17 & 4.95 & & 309.31 & 15.19 \\
\hline & HP11-Site7-W10 & 10.14 & & b.d.l. & 0.4482 & 12.43 & 3.49 & 97.32 & 2.00 & & 163.85 & 7.53 \\
\hline & HP11-Site7-W11 & 9.96 & & b.d.l. & 0.5121 & 28.02 & 5.45 & 228.89 & 4.58 & & 292.43 & 14.25 \\
\hline \multirow[t]{5}{*}{ Site ST9 } & HP11-Site9-W1 & 10.45 & & 0.0119 & 0.5280 & 3.60 & 2.95 & 36.67 & 1.51 & & 81.52 & 3.31 \\
\hline & HP11-Site9-W3 & 10.62 & & 0.0127 & 0.3985 & 2.768 & 2.76 & 6.46 & 0.98 & & 50.58 & 1.72 \\
\hline & HP11-Site9-W4 & 10.46 & & 0.0118 & 0.4094 & 4.80 & 2.98 & 44.96 & 1.76 & & 91.62 & 3.82 \\
\hline & HP11-Site9-W6 & 9.18 & & 0.0079 & 1.6885 & 38.77 & 8.56 & 337.76 & 7.34 & & 380.77 & 18.85 \\
\hline & HP11-Site9-W7 & 10.51 & & 0.0137 & 0.6342 & 4.96 & 3.22 & 47.54 & 1.78 & & 95.84 & 4.03 \\
\hline
\end{tabular}

been detected. Here we report average values of the hydrogen, methane and nitrogen contents (Table 3). Nitrogen is the dominant gas. The methane content is slightly higher at the BdJ spring than at the Kaoris spring. A full analysis of the gas composition will be reported later.

\subsection{Redox potential measurements}

The redox potential was measured in situ using a standard potential electrode at the same time as $\mathrm{pH}$ in the plume of a vent located on the edge of the main carbonate platform of the Bain des Japonais and in the pool of the Kaoris spring
(Fig. 4, Table 4). The redox potential varies linearly with $\mathrm{pH}$ (Fig. 4) from positive (oxidizing) values at low $\mathrm{pH}(+28 \mathrm{mV})$ to negative values at high $\mathrm{pH}(-288 \mathrm{mV})$, consistently with the reducing conditions expected for the alkaline waters due to bubbling of a $\mathrm{H}_{2}$-enriched gas.

The potential of the standard hydrogen electrode is given by

$$
E_{\mathrm{h}}=-\frac{2.303 R T}{F} \mathrm{pH}-\frac{R T}{2 F} \ln p_{H_{2}} .
$$


Table 3. The hydrogen, methane and nitrogen contents of the gases (in volumetric percentage) collected at the springs of the Bain des Japonais and of the Rivière des Kaoris.

\begin{tabular}{lcccc}
\hline Spring & $\begin{array}{c}\text { Number of } \\
\text { samples }\end{array}$ & $\begin{array}{c}\mathrm{H}_{2} \\
(\% \mathrm{~V})\end{array}$ & $\begin{array}{c}\mathrm{CH}_{4} \\
(\% \mathrm{~V})\end{array}$ & $\begin{array}{c}\mathrm{N}_{2} \\
(\% \mathrm{~V})\end{array}$ \\
\hline Bain des Japonais & 18 & $19 \pm 11$ & $13 \pm 4$ & $67 \pm 11$ \\
Rivière des Kaoris & 11 & $24 \pm 11$ & $6 \pm 1$ & $69 \pm 11$ \\
\hline
\end{tabular}

Table 4. Redox potential and pH measured in situ (24 April 2013) at the springs of the Bain des Japonais and of the Rivière des Kaoris.

\begin{tabular}{lrrr}
\hline Spring & $T{ }^{\circ} \mathrm{C}$ & $\mathrm{pH}$ & $E_{\mathrm{h}}(\mathrm{mV})$ \\
\hline Bain des Japonais & 34.7 & 10.48 & -288 \\
& 31.5 & 10.13 & -216 \\
& 29.1 & 9.68 & -172 \\
& 26.5 & 8.88 & -50 \\
& 35.4 & 10.77 & -352 \\
& 30.4 & 10.17 & -219 \\
& 29.7 & 9.93 & -198 \\
& 28.4 & 9.68 & -171 \\
& 28.9 & 9.53 & -163 \\
& 26.9 & 8.73 & 5 \\
& 27.4 & 8.47 & 33 \\
& 27.2 & 8.44 & 19 \\
& 28.6 & 9.46 & -151 \\
& 27.4 & 8.38 & 28 \\
\hline Rivière des Kaoris & 30.5 & 10.95 & -195 \\
\hline
\end{tabular}

In the above expression, $R$ is the gas constant, $T$ the absolute temperature, $F$ the Faraday constant and $p_{\mathrm{H}_{2}}$ the hydrogen partial pressure in the gas phase. The measured $E_{\mathrm{h}} \mathrm{pH}$ values are above the $\mathrm{H}_{2}-\mathrm{H}_{2} \mathrm{O}$ equilibrium line calculated here for a $p_{\mathrm{H}_{2}}$ of 0.2 bars and a temperature of $25^{\circ} \mathrm{C}$ as carried out by Morrill et al. (2013) (Fig. 4). The linear trend depicts the dilution of the reduced hydrothermal fluid by local oxidized seawater. It extrapolates into $E_{\mathrm{h}} \mathrm{pH}$ values reported for a serpentinizing environment (the Cedars site in California; Morrill et al., 2013) that lie on the hydrogen-water redox equilibrium line. These results indicate that water is indeed reduced to hydrogen at surface temperature conditions, but only at very high-pH values (above 11.5) that are not reached in Prony Bay. This key point that relates to the redox conditions of the serpentinizing environment, at the surface and at depth with the ultramafic formation, deserves a detailed separate investigation.

\subsection{The composition of the waters}

Element concentrations of all the analysed samples are reported in Table 2 along with in situ temperatures and $\mathrm{pH}$.

The understanding of the hydrologic regime of the hyperalkaline Prony hydrothermal system requires characterizing the high-pH endmember fluids emitted at each sampling

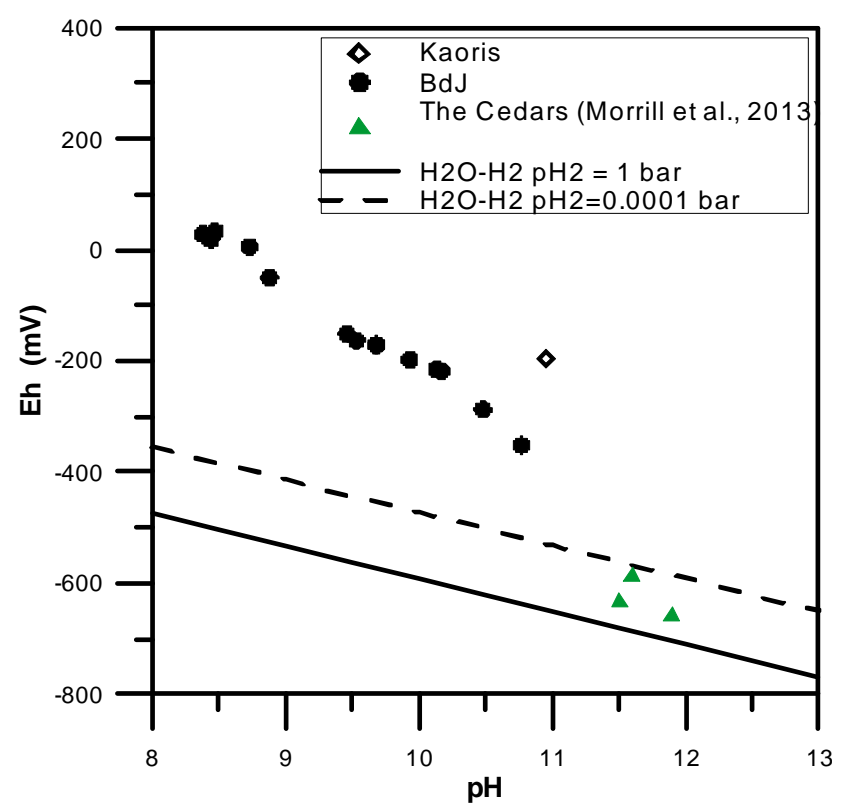

Figure 4. Redox potential measured in situ at the springs of the Bain des Japonais, of the Rivière des Kaoris springs (this work) and of The Cedars site (California; (Morrill et al., 2013). The plain line represent the redox potential calculated at a temperature of $25^{\circ} \mathrm{C}$ for the equilibrium between water and hydrogen at a $\mathrm{H}_{2}(\mathrm{~g})$ partial pressure of 1 bar and the dashed line at a $\mathrm{H}_{2}(\mathrm{~g})$ partial pressure of 0.0001 bar.

site, in order to investigate their variations from one location to another, and therefore constrain the hydrologic pathways. Ideally a series of water samples covering the $\mathrm{pH}$ range from that of the lagoon seawater to the highest measured value should be collected at each site. Then each property (such as temperature or the dissolved element concentrations) should be reported against the concentration of a conservative element used as a measure of mixing and extrapolated (generally to zero) to get the endmember characteristics. Launay and Fontes (1985) have shown that the highest $\mathrm{pH}$ fluids are freshwaters, with salinities lower than $1 \mathrm{~g} \mathrm{~L}^{-1}$. Thus the chloride concentration is a first indication of the extent of mixing.

The element concentrations (Table 2) reported versus $\mathrm{Cl}$ (Fig. 5) indeed show that the dilution range is very large, from seawater salinity to freshwater. The freshest samples are the two samples taken at the Kaoris spring for which calcium and hydroxide are the dominant aqueous compounds (the $\mathrm{Cl}$ content of these samples are 6 and $8 \mathrm{ppm}$ ), leading to a total dissolved load of a few hundred milligrams per litre (Table 2). The 45 water samples follow two trends for all the analysed elements (but for Si and DIC): one for the BdJ spring, and one for the deep sites including the Kaoris spring. These two trends extrapolate to the same endmember at low $\mathrm{Cl}$ concentrations. This indicates a meteoric origin for the high-pH fluids. 

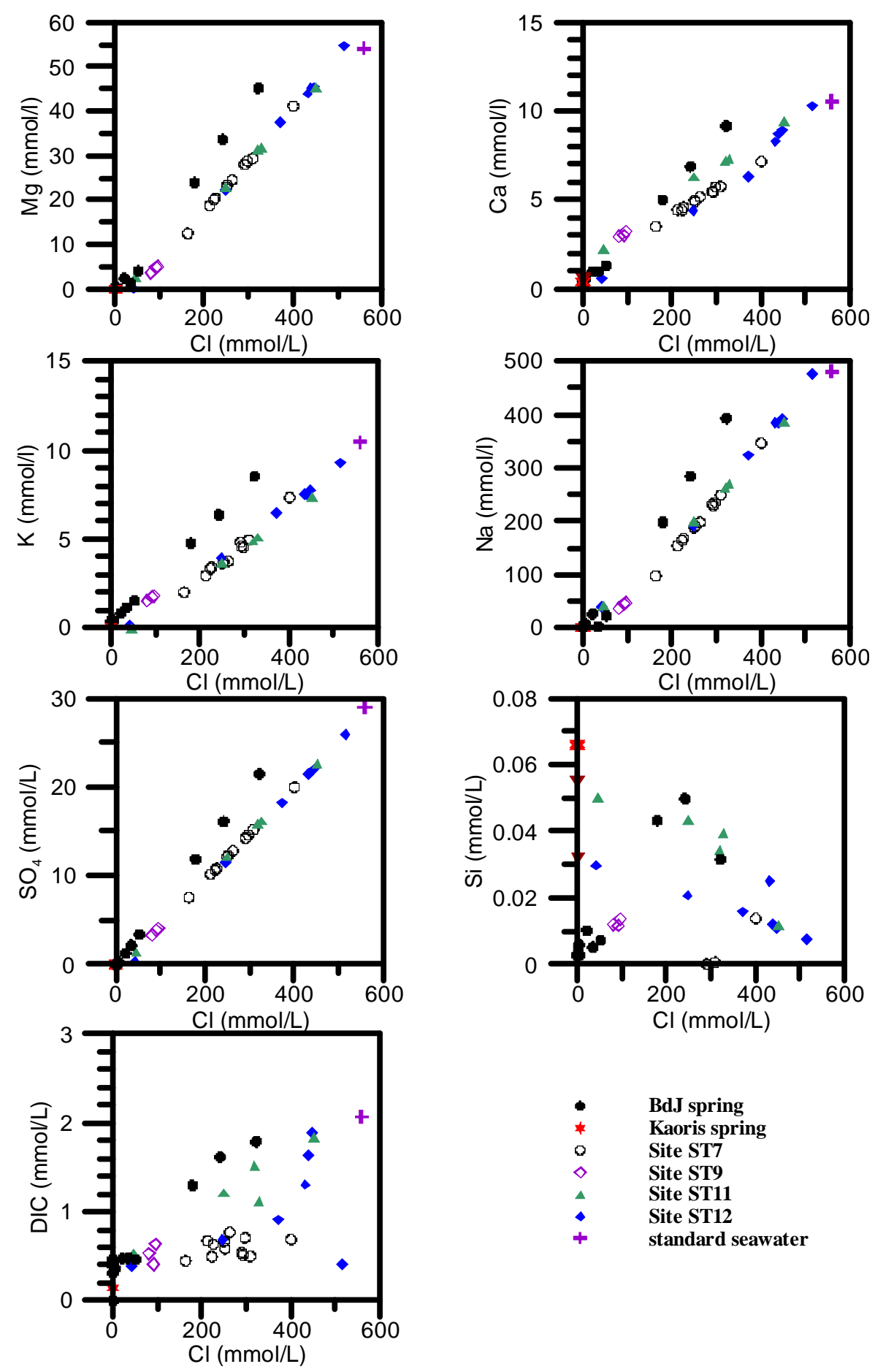

Figure 5. Element concentrations versus the chloride content of the water samples (cross: standard seawater; open circles: Site ST07 (Aiguille de Prony); filled diamonds: Site ST12; open diamonds: Site ST09; triangles: Site ST11; filled circles: Bain des Japonais; star: Rivière des Kaoris; inverted triangle: data from Launay and Fontes (1985) for the Bain des Japonais and the Rivière des Kaoris.

At high $\mathrm{Cl}$ concentrations (Fig. 5), the trend for the deep sites and the Kaoris spring is consistent with the standard seawater concentrations for $\mathrm{Mg}^{2+}, \mathrm{Ca}^{2+}, \mathrm{K}^{+}, \mathrm{Na}^{+}$and $\mathrm{SO}_{4}^{2-}$, whereas the trend for the $\mathrm{BdJ}$ spring is different. Because of the location of the Kaoris spring, i.e. above the sea level at all times including high tide and about $30 \mathrm{~m}$ away from the shore, samples collected there are the only ones that are not contaminated by seawater. The very low salinity of the 
uncontaminated sample of the Kaoris spring also indicates that seawater does not percolate through the ultramafic rock formation; thus preserving the meteoric origin of the high-pH fluids, at least at this location.

$\mathrm{pH}$ for all the samples ranges from the seawater value of 8.2 to a maximum value of about 11 (Table 2). This is comparable to the $\mathrm{pH}$ values reported for Lost City but still far from the highest $\mathrm{pH}$ values found on Earth (Table 1; (Mottl, 2009; Mottl et al., 2004)). The question of the upper pH limit in low temperature serpentinizing environments is still open.

Magnesium is a key element in serpentinizing environments where it is released to the water by $\mathrm{Mg}$ silicate (olivine and pyroxenes) dissolution and scavenged from it by serpentine formation. These reactions keep the $\mathrm{Mg}$ concentration of high-pH waters at very low values.

What the element concentrations reported versus $\mathrm{pH}$ depicts is not the evolution of the serpentinizing fluid during its circulation in the ultrabasic formation, but the dilution of the high-pH, low-salinity fluid by seawater at the discharge locations in the lagoon. In Oman these high-pH fluids are diluted by the runoff waters (Chavagnac et al., 2013b; Table 1). In the samples that we have collected in Prony Bay, the $\mathrm{Mg}$ content drops from the reference seawater value of $54.1 \mathrm{mmol} \mathrm{L}^{-1}$ at a pH of 8.1 (Millero, 2006) to values as low as $0.006 \mathrm{mmol} \mathrm{L}^{-1}$ at a $\mathrm{pH}$ of 11.08 . Note, however, that the $\mathrm{Mg}$ content decreases only slightly for $\mathrm{pH}$ values between 8.1 and 10 and markedly toward higher $\mathrm{pH}$ values with a slope of about -2 (Fig. 6), consistently with a control of the $\mathrm{Mg}$ concentration of the waters by brucite formation (see below). The $\mathrm{Mg}$ concentrations of the waters of the Kaoris spring $(\mathrm{pH}$ 10.80) and of the only sample collected at the deep sites at a pH higher than 10.6 (sample HP11-Site12-W1, Table 2) were not detected by ICP-OES, although very low values (down to $0.01 \mathrm{mmol} \mathrm{L}^{-1}$ ) for the BdJ spring could be measured. This nevertheless shows that the $\mathrm{Mg}$ content of the water samples at $\mathrm{pH} 11.0$ for the deep site and at $\mathrm{pH} 10.8$ for the Kaoris spring is very low and that the two distinct trends merge to a very low $\mathrm{Mg}$ concentration at high-pH (Figs. 5 and 6). At intermediate $\mathrm{pH}$ values (10-10.5), the difference between the two trends in the $\mathrm{Mg}$ content can be as large as 1 order of magnitude, as observed for the $\mathrm{Ca}$ concentrations (and to a lesser extend for $\mathrm{Na}$ and K) (Fig. 6).

The $\mathrm{Na}$ and $\mathrm{Cl}$ concentrations also exhibit two different trends at $\mathrm{pH}$ values above 10 , meaning that two waters of the same $\mathrm{pH}$ can have different salinities (Fig. 6). Of particular interest is the sample HP11-Site12-W1 which is the water sample of the deep sites having the highest $\mathrm{pH}$ value (11). Its chloride and sodium concentrations do plot on the trend defined by the data for the deep sites, but they are higher by more than an order of magnitude than the samples of the BdJ and the Kaoris springs at the same $\mathrm{pH}$ values. Also noteworthy is that its $\mathrm{Ca}$ and $\mathrm{K}$ concentrations lie on the data trend of the BdJ spring. ST11 located on the eastern side of the bay could be different from the others. Unfortunately, no sample with a $\mathrm{pH}$ above 10.62 could be collected at the nearby site ST09 (Fig. 1). In a study of the alkaline waters of the Oman and Liguria ophiolites, Chavagnac et al. (2013b) proposed that the somewhat high salinity of some of these waters could be due to their interaction with the metasedimentary formation underlying the ophiolite nappe, indicating that the circulation of the high-pH fluids would not be confined to the ultramafic formation. This could be the case for Prony Bay.

The data reported in this work for the Kaoris spring are consistent with those given by Launay and Fontes (1985) (the same data is given in Cox et al., 1982 and by Barnes et al., 1978), meaning that the composition of the high-pH fluids have not markedly changed over the last thirty years or so. This is also the case for the present data for the BdJ spring when compared to the composition given by Launay and Fontes (1985). There are similarities but also marked differences between the waters at $\mathrm{pH} 10.8-11$ at the $\mathrm{BdJ}$ and the Kaoris springs (Table 2). The waters at $\mathrm{BdJ}$ are more saline than at Kaoris. This can be in part explained by a contamination by seawater, therefore leading to higher $\mathrm{Na}, \mathrm{K}$ and $\mathrm{Cl}$ concentrations at $\mathrm{BdJ}$ compared to Kaoris. The Ca concentration is the same at both locations, but the silica concentration is 1 order of magnitude higher at Kaoris than at BdJ. This cannot be due to the alteration of the concrete used to build the spa: first because the aqueous silica concentration reported here is the same as the one measured by Launay and Fontes (1985) at a time when the spring was not arranged as a pool, and also because at the time of the HYDROPRONY cruise the water flow was significant and the sample was taken at the fluid outlet at the bottom of the pool.

Chloride-normalized concentrations (Fig. 7) allow us to take into account the dilution effects and reducing the dispersion of the data. The variation of chlorine-normalized element concentrations as a function of $\mathrm{pH}$ exhibits a major trend break at a pH of around 10 (Fig. 7), as similarly shown by the Mg data (Fig. 6). They are equal to the reference seawater values at $\mathrm{pH}$ values below $\mathrm{pH} 10$ for all the sites other than the BdJ spring. The $\mathrm{pH}$ value of 10 delimitates the marine environment at low $\mathrm{pHs}$ from the hyperalkaline environment (which (Chavagnac et al., 2013b) already observed for Oman and Liguria). Reactive dissolved elements or compounds such as DIC differ from their standard seawater Cl-normalized concentration (when it can be defined, which cannot be done for dissolved silica).

To summarize, the present results show that the hyperalkaline waters emitted at all sites in Prony Bay are of meteoric origin and that these high-pH fluids may mix with seawater at the discharge, but not in the subsurface. The waters of the Kaoris spring appear to be the most pristine. There are differences in water compositions between the deep sites and the other sites in the intermediate $\mathrm{pH}$ range, but the endmember compositions at the highest $\mathrm{pH}$ values are about the same. A difference in salinity may be noticed, but the scarcity of the data at the highest $\mathrm{pH}$ values does not allow any firm conclusion for now. 

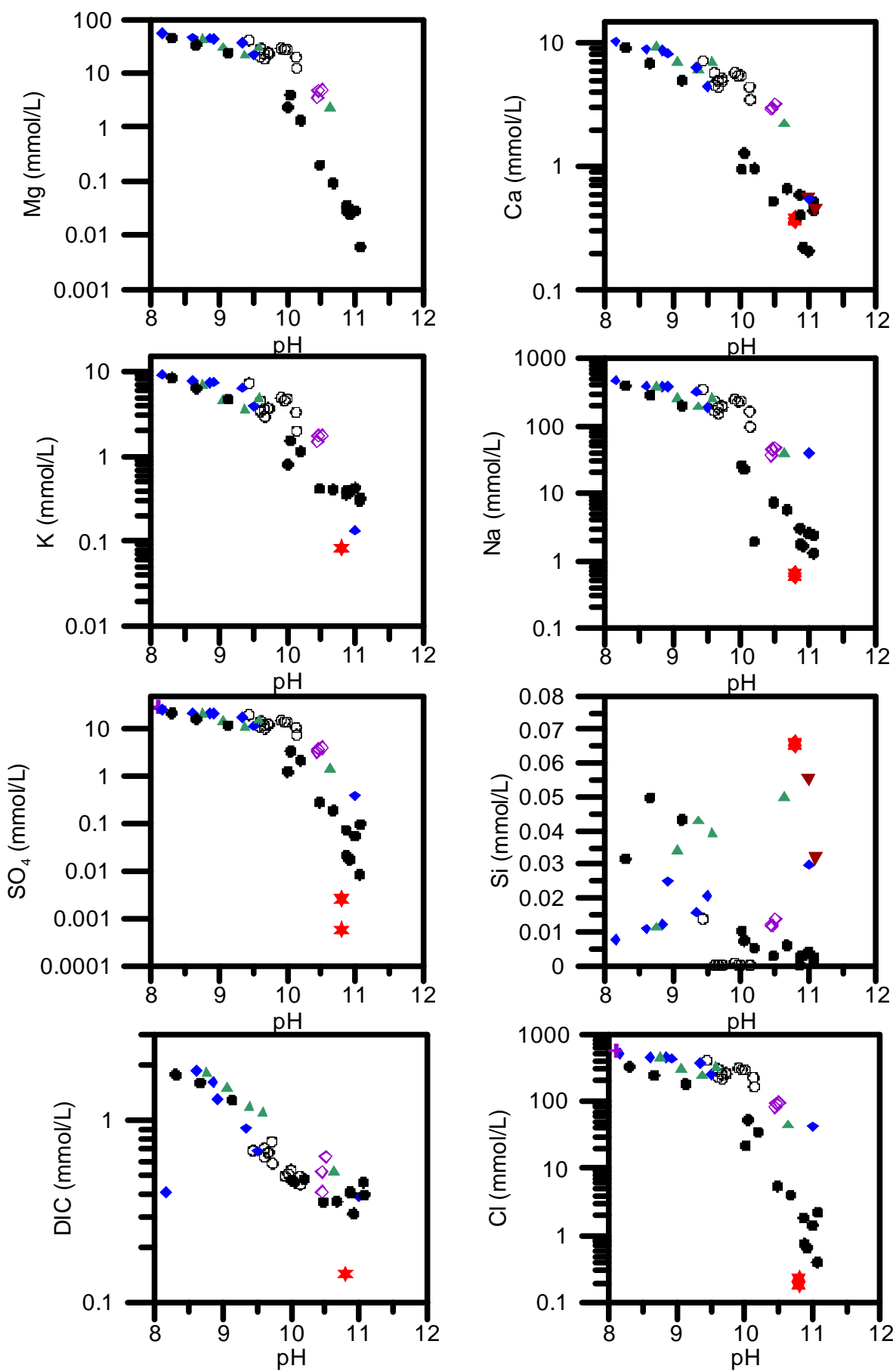

Figure 6. Element concentrations of the collected water samples versus pH. Same symbols as for Fig. 5.

Minerals may form when $\mathrm{Ca}^{2+}-\mathrm{OH}^{-}$type alkaline waters mix with seawater, which we investigate in the following section through the calculation of their saturation states.

\section{The mineral saturation states}

The number of dissolved elements and compounds determined by the chemical analysis defines the composition of the waters (Table 2) and therefore the chemical system (in a thermodynamic sense) that is used to describe the natural object. Here we analysed the major elements (along with 

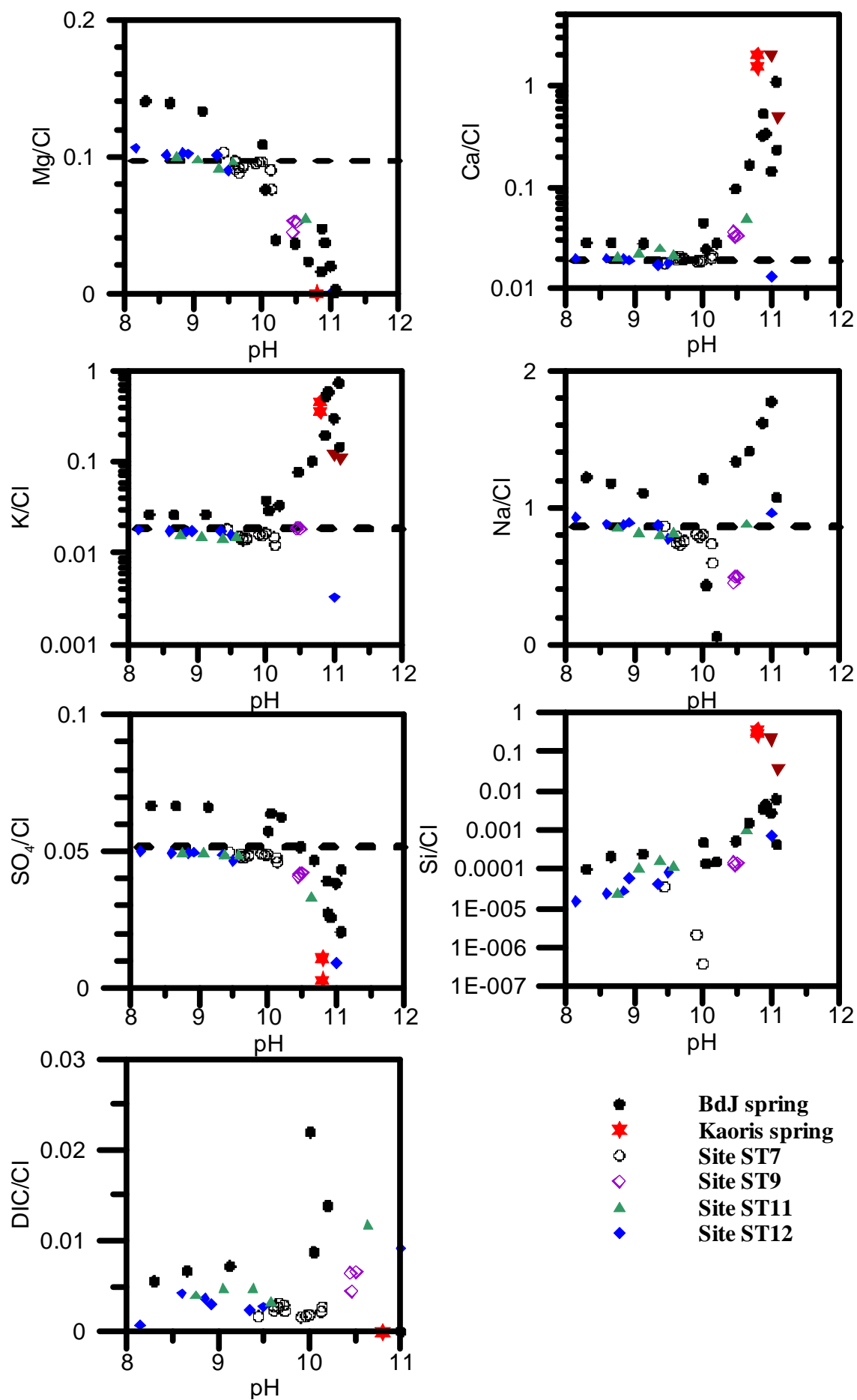

Figure 7. Chloride-normalized element concentrations versus pH. Same symbols as for Fig. 5. The dashed line represents the value for standard seawater (Millero, 2006).

$\mathrm{SiO}_{2}(\mathrm{aq})$ ), so that the chemical system, in which the compositions of the Prony Bay waters are given, is the Na-K$\mathrm{Ca}-\mathrm{Mg}-\mathrm{Cl}-\mathrm{SO}_{4}-\mathrm{DIC}-\mathrm{SiO}_{2}-\mathrm{H}_{2} \mathrm{O}$ system. The thermodynamic state of the HYDROPRONY water samples has been addressed through the calculation of the mineral saturation in- dices using the PHREEQC code. The saturation index is defined as

$\Omega=\log \left[\frac{Q}{K_{\mathrm{sp}}}\right]$, 
where $Q$ is the ionic product (the product of the ionic activities) and $K_{\text {sp }}$ the solubility product of the given mineral.

The choice of the database is of primary importance as different databases contain either different sets of minerals (e.g. portlandite which is not included in the phreeqc.dat database), or different values of the mineral solubility products. It is beyond the scope of the present paper to check the thermodynamic data for all the minerals relevant to the serpentinizing environment. We focused on $\mathrm{Ca}$ and $\mathrm{Mg}$ carbonates and brucite which have been observed to form in the concretions (Pisapia and the HYDROPRONY scientific team, 2012) and also on various forms of silica (quartz, chalcedony, amorphous silica) that have been shown to play a role in the control of aqueous silica in the alkaline waters of Oman (Chavagnac et al., 2013a, b) .

Values for the brucite solubility product reported in the literature (e.g. Harvie et al., 1984; Königsberger et al., 1999; Lambert and Clever, 1992) vary over about 1 order of magnitude. We retained for this mineral the value recently proposed by Xiong (2008) in a study based on new solubility data. Thermodynamic data for the Ca carbonates and for the silica minerals between the various sources (i.e. data bases provided with PHREEQC) were found consistent. However, there are discrepancies between the various values of the thermodynamic properties of the $\mathrm{Mg}$ carbonates available in the literature (see for example Bénézeth et al., 2011, for magnesite). Values for double salts like dolomite, huntite, etc., are very uncertain, likely as a result of the difficulty of synthesizing these minerals at low temperature (Bénézeth et al., 2011). The saturation state values reported here are certainly subject to changes when improved thermodynamic data become available, but they indicate some interesting trends.

The calculations have been carried out using the concentration of all the elements (Table 2) in a molarity scale and $\mathrm{pH}$, and the dissolved inorganic carbon content as the input parameter for the carbonate system.

The saturation indices have first been calculated assuming that the relationship between $\mathrm{T}$ and $\mathrm{pH}$ exhibited for the Bain des Japonais samples (Fig. 3) was valid for all the sites, as a way of estimating the temperature of the fluids at the deep sites.

\subsection{Hydroxides (brucite and portlandite)}

The Prony Bay water samples reach saturation with respect to brucite at a pH of 9.5 (Fig. 8) and its saturation state continues to increase up to a $\mathrm{pH}$ of 10 where it levels off to a $\log \left(Q / K_{\text {sp }}\right)$ of about 1.5 for the Bain des Japonais. This coincides with the marked change of the $\mathrm{Cl}$-normalized element concentrations (Fig. 7): decrease of $\mathrm{Mg} / \mathrm{Cl}, \mathrm{Na} / \mathrm{Cl}$ and $\mathrm{SO}_{4} / \mathrm{Cl}$, and increase of $\mathrm{K} / \mathrm{Cl}, \mathrm{Si} / \mathrm{Cl}$ and $\mathrm{DIC} / \mathrm{Cl}$.

Portlandite $\left(\mathrm{Ca}(\mathrm{OH})_{2}\right)$ has been found to rarely form in the alkaline springs of Oman (Neal and Stanger, 1984a). It is largely undersaturated in the Prony Bay environment.

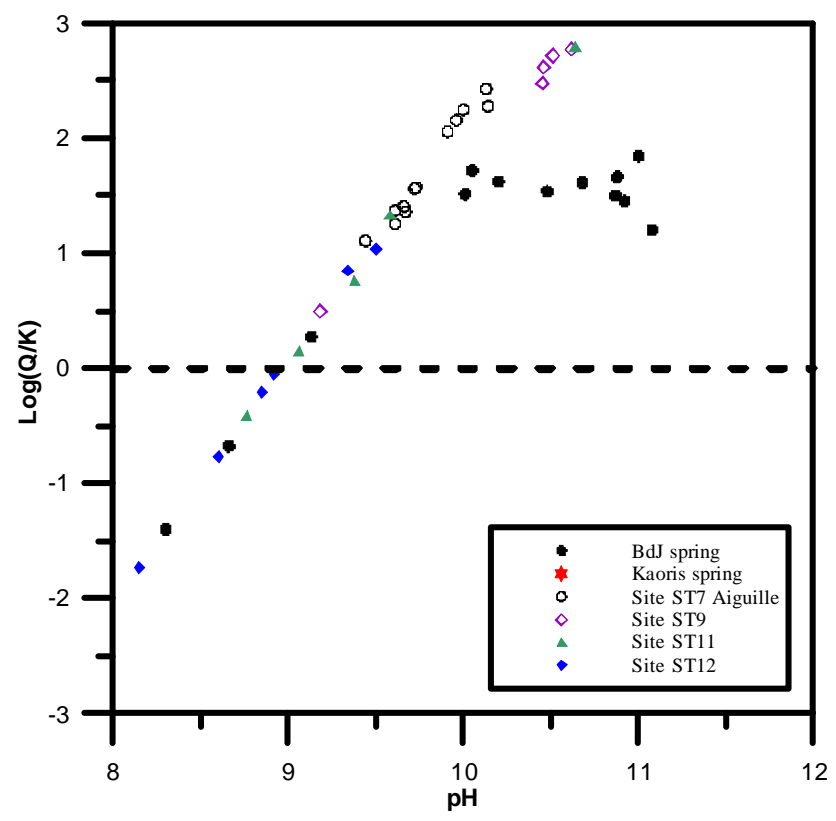

Figure 8. The brucite saturation state of Prony waters versus $\mathrm{pH}$. Same symbols as in Fig. 5. The horizontal dashed line represents the chemical equilibrium.

\subsection{Ca carbonates and silica}

The Prony Bay water samples are supersaturated with respect to calcite (as well as aragonite) throughout the whole $\mathrm{pH}$ range at supersaturation values commonly found in the marine environment (Fig. 9).

All forms of silica are undersaturated over the whole $\mathrm{pH}$ range. This is the case for marine waters (low $\mathrm{pH}$ ) and for very alkaline waters in which silica becomes very soluble (see the example of Oman and Liguria in Chavagnac et al. (2013b).

\subsection{Mg carbonates, dolomite and huntite}

Under this heading we designate the Mg carbonates themselves: magnesite and all forms of hydrated magnesium carbonate: $\mathrm{MgCO}_{3} \cdot p \mathrm{H}_{2} \mathrm{O}$ and the double salts $\mathrm{Mg}$ hydroxocarbonates $m \mathrm{MgCO}_{3} \cdot n \mathrm{Mg}(\mathrm{OH})_{2} \cdot p \mathrm{H}_{2} \mathrm{O}$ (Table 5). The composition of these double salts can be understood as intermediate steps with increasing $\mathrm{CO}_{3} / \mathrm{OH}$ ratios from the hydroxide endmember brucite to the carbonate magnesite. Hydrated $\mathrm{Mg}$ carbonates $\mathrm{MgCO}_{3} \cdot p \mathrm{H}_{2} \mathrm{O}$ and various forms of $\mathrm{Mg}$ hydroxo-carbonates are metastable phases mainly forming through biological processes during the evolution of high-pH waters in contact with the atmosphere, such as the Atlin playa lake in British Columbia (Power et al., 2007).

The saturation states of magnesite, hydromagnesite, artinite, huntite and dolomite (Fig. 10) indicate very large supersaturations and a maximum value at a $\mathrm{pH}$ of around 10 . These maxima are very well marked for the Bain des Japonais. 
Table 5. Chemical formula of various $\mathrm{Mg}-\mathrm{Ca}$ carbonates (the numbers $m, n$ and $p$ correspond to the following formula: $\left.m \mathrm{MgCO}_{3} \cdot n \mathrm{Mg}(\mathrm{OH})_{2} \cdot p \mathrm{H}_{2} \mathrm{O}=(m+n) \mathrm{Mg} \cdot m \mathrm{CO}_{3} \cdot n \mathrm{OH} \cdot p \mathrm{H}_{2} \mathrm{O}\right)$.

\begin{tabular}{cccll}
\hline$m$ & $n$ & $p$ & Name & Formula \\
\hline 1 & 0 & 0 & Magnesite & $\mathrm{MgCO}_{3}$ \\
1 & 0 & 2 & Barringtonite & $\mathrm{MgCO}_{3} \cdot 2 \mathrm{H}_{2} \mathrm{O}$ \\
1 & 0 & 3 & Nesquehonite & $\mathrm{MgCO}_{3} \cdot 3 \mathrm{H}_{2} \mathrm{O}$ \\
1 & 0 & 5 & Lansfordite & $\mathrm{MgCO}_{3} \cdot 5 \mathrm{H}_{2} \mathrm{O}$ \\
1 & 1 & 3 & Artinite & $\mathrm{MgCO}_{3} \cdot \mathrm{Mg}(\mathrm{OH})_{2} \cdot 3 \mathrm{H}_{2} \mathrm{O}$ \\
4 & 1 & 5 & Dypingite & $4 \mathrm{MgCO}_{3} \cdot \mathrm{Mg}(\mathrm{OH})_{2} \cdot 5 \mathrm{H}_{2} \mathrm{O}$ \\
4 & 1 & 5 & Hydromagnesite & $4 \mathrm{MgCO} 3 \cdot \mathrm{Mg}(\mathrm{OH})_{2} \cdot 4 \mathrm{H}_{2} \mathrm{O}$ \\
0 & 1 & 0 & Brucite & $\mathrm{Mg}(\mathrm{OH})_{2}$ \\
\hline
\end{tabular}

\section{Discussion and conclusions}

The composition of the waters collected at the hyperalkaline springs of Prony Bay shows that the high-pH fluids are of meteoric origin, as indicated by the low salinity of the highest $\mathrm{pH}$ waters. These waters are of the $\mathrm{Ca}-\mathrm{OH}$ type, as already described in continental serpentinizing environments (Table 1) and clearly shown by the most pristine sample (that of the Kaoris spring) for which aqueous calcium and hydroxide are the dominant dissolved species, all other solutes exhibiting trace concentrations. The highest $\mathrm{pH}$ values found at Prony Bay are close to the values found at Lost City, but lower than the highest alkaline values naturally found to date on Earth (in the Mariana forearc, Mottl et al., 2004). A peculiarity of Prony Bay that makes this site unique is that the low-salinity alkaline waters discharge into the marine environment and mix with seawater.

As stated in the introduction (Table 1), hyperalkaline systems can be characterized first by the nature and composition of the high-pH endmembers discharging at springs, but also by the type of environment in which these peculiar high$\mathrm{pH}$ fluids discharge and the type of local waters with which they can mix. For the case of Prony Bay, this translates into two questions: (1) the evolution of the recharge waters (of meteoric origin) during their interaction with the ultramafic basement up to the discharge locations (springs) and (2) the mineral formation induced by mixing these high-pH, lowsalinity waters with the lagoon seawater (Fig. 11).

The composition of the water samples reported in this work (Figs. 5 and 6) shows that the main difference is between the Bain des Japonais and other springs, in the intermediate $\mathrm{pH}$ range. Within the dispersion of the data, the endmember fluids (i.e. the samples with the highest $\mathrm{pH}$ values) of the BdJ spring, of the deep sites and of the Kaoris spring are similar. This would mean that even if the flow paths are different, from the recharge zone to the springs (Fig. 11), the residence time of the waters in the ultramafic basement is long enough for the waters to acquire similar compositions. The temperature of the nearby river is up to $15^{\circ} \mathrm{C}$ lower than those of the hyperalkaline springs (Launay and Fontes,

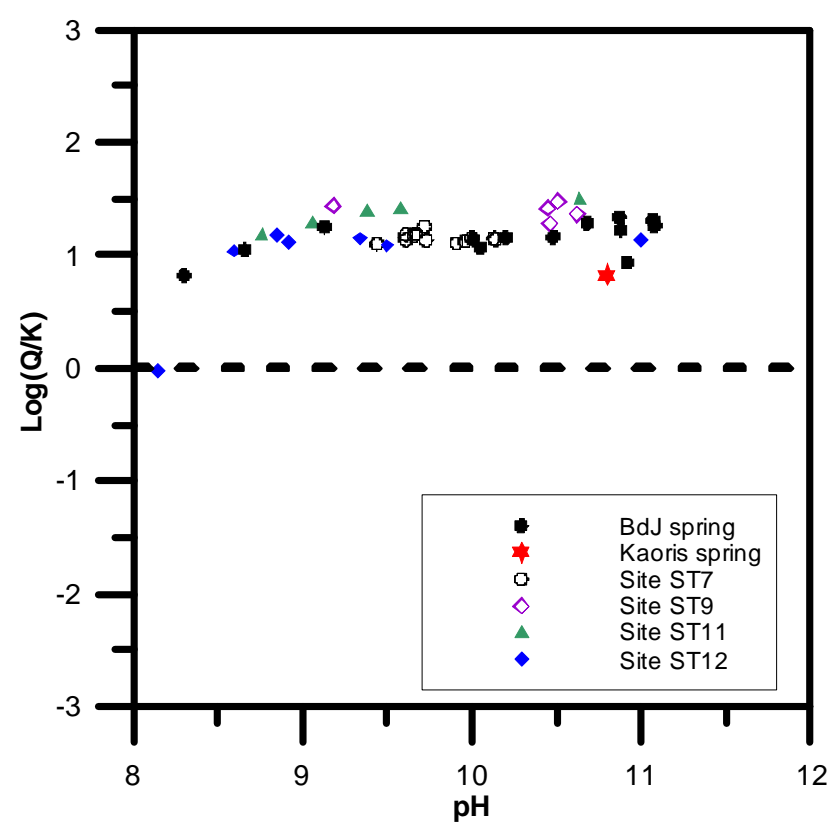

Figure 9. The calcite saturation state of the Prony Bay waters versus $\mathrm{pH}$. Same symbols as for Fig. 5. The horizontal dashed line represents the chemical equilibrium.

1985), arguing for water heating (either due to the geothermal gradient or to heat generated by serpentinization) during its circulation within the ultramafic substratum, and conductively cooling during its ascent to the surface. A tentative value of the geothermal gradient of $20^{\circ} \mathrm{C} \mathrm{km}^{-1}$ in New Caledonia would then suggest that water circulates down to about a kilometre below the surface. The hydrologic regime and pathways of fluid circulation in ophiolites, in New Caledonia and elsewhere (Chavagnac et al., 2013b) are still open questions, that are also addressed in related topics such as carbon capture and sequestration (Arcilla et al., 2011).

The water samples collected at the BdJ spring share common overall characteristics with the other sites, but nevertheless display a different trend. The Bain des Japonais sample with the lowest $\mathrm{pH}(8.3$, Table 2$)$ was collected about $20 \mathrm{~m}$ away from any vent. Still this sample has a chloride content (322 mmol L-1, Table 2) much lower than that of standard seawater. This can be due to two combined causes. On one hand, the western branch of the Baie du Carénage is very shallow so that the marine waters can be readily diluted by the nearby creek, the Rivière du Carénage (Fig. 1). On the other hand, waters in the southern lagoon of New Caledonia can have a long residence time (i.e. a slow renewal rate) (Ouillon et al., 2010). The tide effects are very attenuated at the end of the Baie du Carenage, where the BdJ spring is located. Such hydrodynamic conditions create an altered "marine" endmember that mixes with the high-pH fluids produced by serpentinization; thus leading to the trend in which the BdJ spring is different from that of the other sites, where 

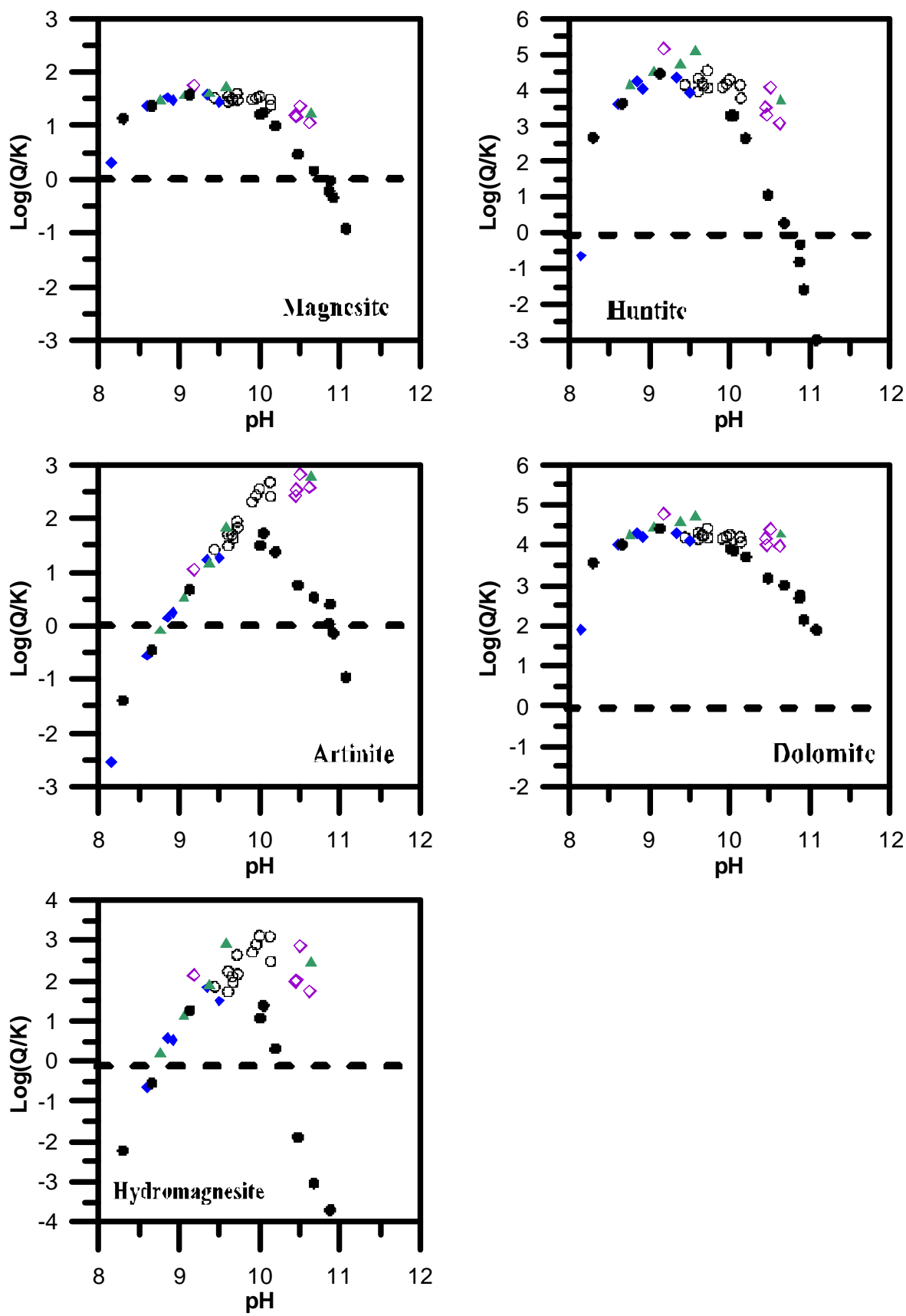

Figure 10. The saturation state of various magnesium/calcium carbonates of the Prony Bay waters versus pH. Same symbols as for Fig. 5 . The horizontal dashed line represents the chemical equilibrium.

seawater of standard salinity is the marine endmember of the mixtures. This is further indicated by the Cl-normalized concentrations of the dissolved elements (Fig. 7).

At intermediate $\mathrm{pH}$ values (around 10.5), the $\mathrm{Mg}$ content of the fluids is lower by an order of magnitude at the Bain de Japonais compared to the values at the deep sites. Still the two trends show the same major change at $\mathrm{pH} 10$. The thermodynamic calculations reveal that this change occurs when the brucite saturation index reaches a constant value $\left(\log \left(Q / K_{\mathrm{sp}}\right)\right.$ higher than 1.5$)$ that may be indicative of brucite formation from a supersaturated solution, with a supersaturation at the deep sites higher than that at the Bain des Japonais. Brucite forms at the vents when high-pH waters mix with Mg-rich seawater. Brucite formation due to mixing of two water types has already been evidenced in the alkaline springs of Oman where magnesium is brought by the runoff waters and hydroxide by the high-pH fluids (Chavagnac et al., 2013a, b). This mode of brucite formation is different 


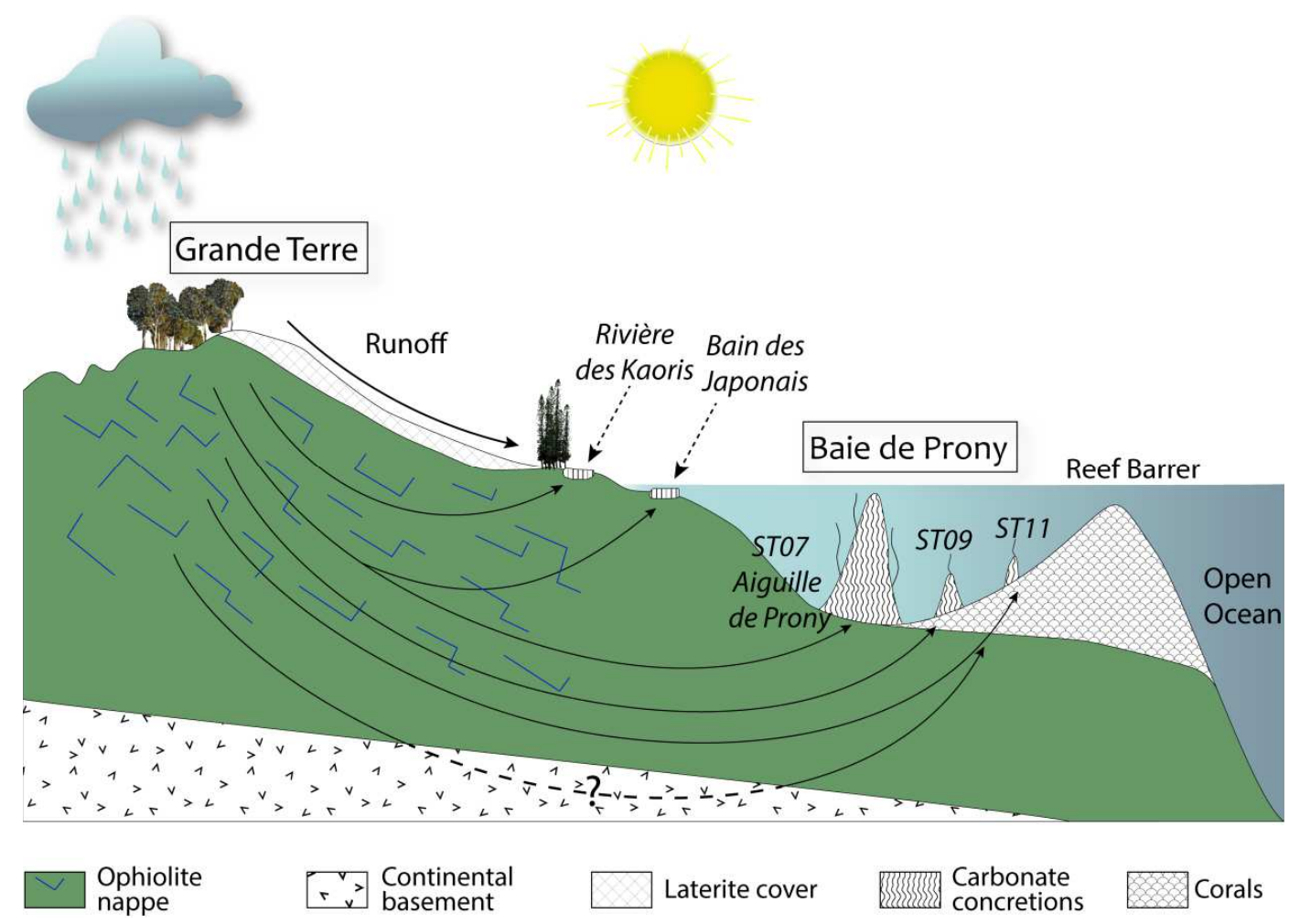

Figure 11. A sketch of the general geological setting of the Prony hydrothermal field (PHF, not to scale). The ophiolite nappe is covered by a thick lateritic cover. The hydrothermal system is fed by meteoric waters that percolate through the densely fractured peridotites and discharge at springs in the lagoon where the high-pH waters mix with seawater. Note the position of the spring of the Rivière des Kaoris above sea level, while the Bain des Japonais is uncovered at low tide and the other springs always under water. The arrows tentatively indicate the pathways of the fluid percolation and point to the question of the nature of the geological formations leached by the waters: ophiolite nappe, continental basement and/or coral formations.

from the formation of brucite during the serpentinization process itself, in which magnesium is released by $\mathrm{Mg}$ silicate dissolution, a reaction consuming $\mathrm{H}^{+}(\mathrm{aq})$, therefore increasing the aqueous phase $\mathrm{pH}$ leading to the formation of brucite as a secondary mineral (Chavagnac et al., 2013b). In a totally different environment (concrete alteration by drainage waters in Austrian tunnels), Rinder et al. (2013) have also found that brucite forms at supersaturation values close to those found here. This may indicate that brucite precipitation occurs only when a supersaturation threshold is reached.

The saturation indices of the Mg-bearing carbonate minerals display a maximum value at intermediate $\mathrm{pH}$ values (around 10; Fig. 10). These maxima are very large, indicative of marked supersaturation. As stated above, the values of solubility products of these carbonate minerals are still a subject of debate, despite recent improvements (Bénézeth et al., 2011) and the calculated saturation indices may be tentative values. A change in the solubility product of a given mineral would shift the entire data set in Fig. 10, but not change its shape. The supersaturation at a $\mathrm{pH}$ of around 10 may thus indicate the most favorable conditions (the highest driving forces) for these minerals to form through an inorganic process. It is nevertheless well known that magnesite and dolomite do not form at low temperature through simple inorganic precipitation (Morse et al., 2007), although recent works brought new insights into the role of magnesium hydration (Xu et al., 2013) and of surface chemistry (Roberts et al., 2013). This would mean that these high supersaturations at intermediate $\mathrm{pH}$ values point to the hindrance of mineral formation (metastability) and not to quantitative precipitation. However, mineralogical observations indicate that organomineralization drives the formation of $\mathrm{Mg}$ carbonates in the concretions (Pisapia et al., 2013). At the Bain des Japonais, there is a marked dominance of brucite, along with the formation of aragonite. Minerals in lesser amounts include magnesium carbonates and double layered hydroxides (nesquehonite, hydrotalcite, iowaite) (Pisapia et al., 2014). Such mineral assemblages are also observed in the concretions collected at the deep sites actively discharging the high$\mathrm{pH}$ fluids. When the vents are no longer active, seawater percolates deeper into their structure, therefore modifying the mineralogical composition of the concretions, with an increasing amount of calcite. These results emphasize the intricate role of the potential energy provided by the inorganic process (mineral supersaturation) and the influence of microorganisms that may take advantage of these favorable 
energetic conditions to induce mineral formation, thus breaking down the metastability.

The temperature difference between the venting fluids and the lagoon waters is not very large (at most about $15^{\circ} \mathrm{C}$ ). The mixing process depicted by the data in Fig. 5 and 6 creates marked $\mathrm{pH}$, salinity and concentration gradients, leading to mineral supersaturations (Fig. 10) and favorable conditions for the development of adapted ecosystems (Postec et al., submitted; Quéméneur et al., 2014). At active vent sites (especially the deep ones), a combination of inorganic precipitation and bio- and organomineralization processes leads to the formation of concretions and needle-like structures that can grow up to the size of the Aiguille de Prony. Some of these formations grow around a central conduit where the high-pH fluids circulate. At such places the concretion walls are not very thick so that the $\mathrm{pH}$ varies from 8.2 at the outside (seawater in the normal lagoon marine environment) to 11 (the alkaline hydrothermal fluid in the central part) over a distance of $10 \mathrm{~cm}$ or so. Also these concretions are very porous. It is then likely that the tortuosity of the flow within the porous material creates complex mixing patterns, with very different conditions of $\mathrm{pH}, E_{\mathrm{h}}$, salinity and temperature over very short distances. The structure of these concretions also depends on the age and on the vigour of the hydrothermal activity of the vent (Pisapia et al., 2013). Inside these concretions alkaliphilic microorganisms can grow in the high-pH, low-salinity fluid while the outside part is in contact with the normal lagoon marine environment (Pisapia et al., 2013; Quéméneur et al., 2014). The very strong concentration and salinity gradients found in the hydrothermal system of Prony Bay are unique features. It is very different from the Lost City hydrothermal field where the high-pH hydrothermal fluid is altered seawater of the same salinity as normal seawater (Kelley et al., 2001) .

The brucite saturation state has been calculated using the PHREEQC code (with the phreeqc.dat data base) using the input composition data in the $\mathrm{Na}-\mathrm{K}-\mathrm{Ca}-\mathrm{Mg}-\mathrm{Cl}-\mathrm{SO}_{4}-\mathrm{DIC}-$ $\mathrm{H}_{2} \mathrm{O}$ chemical system which is here used as a model of the real solution (see the discussion in Monnin and Hoareau, 2010, of the difference between model seawater and seawater models). This procedure neglects eventual dissolved compounds that may act as ligands of aqueous magnesium. Such aqueous complex formation would modify the thermodynamic properties of aqueous magnesium by lowering its total (or stoichiometric) activity coefficient. As a result complexation stabilizes the aqueous phase at the expense of minerals, thereby increasing their solubility. Magnesium is indeed easily complexed by organic molecules (Holm, 2012; Krause et al., 2012) (a common method to analyse magnesium in aqueous solutions is based on a titration using $\mathrm{Mg}$ complexation by EDTA).
Serpentinization is a complex combination of dissolution/precipitation and redox reactions. The oxidation of metals (mainly iron) contained in peridotites is accompanied by the reduction of water, leading to the simultaneous production of high-pH waters and of hydrogen (Chavagnac et al., 2013b). Further reactions of hydrogen with either organic matter or oxidized carbon compounds may lead to the formation of methane (and to a lesser extend longer chain hydrocarbons or simple organic anions such as formate (Lang et al., 2010) through Fisher-Tropsch type reactions (Prokurovski, 2010). Indeed gases emitted at the alkaline springs of Prony Bay are enriched in $\mathrm{H}_{2}$ and $\mathrm{CH}_{4}$. They serve as important energy and carbon sources for microorganisms that thrive in the porous chimney walls. Various degrees of mixing of the alkaline fluid with oxygenated ambient seawater also provide potential electron acceptors (such as sulfates, nitrates or oxygen) crucial for many microbial metabolisms. This was recently evidenced by a molecular survey conducted on Prony Bay concretions (Quéméneur et al., 2014) which showed the dominance of microbial metabolic groups using either of $\mathrm{H}_{2}$ or $\mathrm{CH}_{4}$ as electron donors for their growth under the anaerobic conditions found in the high-pH fluids. These metabolic groups notably include Methanosarcinales, a group of archaea including both hydrogenotrophic methanogens and members responsible for the anaerobic oxidation of methane, a reaction thermodynamically unfavorable unless coupled with sulfate or nitrate reduction via syntrophic association (consortia) with sulfate or "nitrates" reducing bacteria (Knittel and Boetius, 2009). Remarkably the Methanosarcinales described in Prony Bay are very similar to those previously detected in the Lost City hydrothermal field (Brazelton et al., 2006; Schrenk et al., 2004). In the high-pH springs of Prony Bay, sulfate-reducing bacteria of the Deltaproteobacteria group are also well represented (Quéméneur et al., 2014) as is the case at Lost City (Brazelton et al., 2006). Aerobic respiration of hydrogen or methane (and other $\mathrm{C} 1$ compounds) is also most likely active in the concretions as strongly suggested by the abundance of sequences related to hydrogenotrophic bacteria of the Burkholderia class, such as Hydrogenophaga and many taxa representing methylotrophic bacteria (Quéméneur et al., 2014).

Lastly, the carbonate concretions and the hyperalkaline springs of the Prony hydrothermal system provide a unique example of the interface between a continental ultramafic formation and the marine environment, with peculiar links between geology, fluid chemistry and microbial activity (Perner et al., 2013; Toner et al., 2013). 
Acknowledgements. We deeply acknowledge the efficient work of the scuba divers Eric Folcher, Bertrand Bourgeois and John Butscher, of the IRD Center in Nouméa, with the help of Régis Hocdé (who also provided a key administrative and logistical support), who collected the samples in dark waters in a shark inhabited environments. We thank Captain Jean-François Barazer and his crew on board the R/V Alis. Anne-Marie Cousin skillfully designed the sketch of the PHF. CM warmly thanks Dominique Cluzel, Margot Godard and Julien Collot for this glorious day at the springs in the Prony Bay in April 2013. The HYDROPRONY cruise would not have taken place without the full support of the Direction Scientifique de l'IRD. This project was financially supported by IRD and by the French national CNRS programs EC2CO-Biohefect/Ecodyn/Dril/MicrobiEn (MicroProny).

Edited by: E. J. Javaux

\section{References}

Arcilla, C. A., Pascua, C. S., and Alexander, W. R.: Hyperalkaline groundwaters and tectonism in the Philippines: significance to natural Carbon Capture and Sequestration, in: 10th International Conference on Greenhouse Gas Control Technologies, Energy Procedia, edited by: Gale, J., Hendriks, C. and Turkenberg, W., 5093-5101, 2011.

Avias, J.: Overthrust structure of the main ultrabasic new caledonian massives, Tectonophysics, 4, 531-541, 1967.

Barnes, I. and O'Neil, J.: The relationship between fluids in some fresh alpine-type ultramafics and possible modern serpentinization, Western United States, Geol. Soc. Am. Bull., 80, 19471960, 1969.

Barnes, I., O’Neil, J. R., and Trescases, J. J.: Present day serpentinization in New Caledonia, Oman and Yugoslavia, Geochim. Cosmochim. Ac., 42, 144-145, 1978.

Bénézeth, P., Saldi, G. D., Dandurand, J.-L., and Schott, J.: Experimental determination of the solubility product of magnesite at 50 to $200^{\circ} \mathrm{C}$, Chem. Geol., 286, 21-31, 2011.

Besson, P., Degboe, J., Berge, B., Chavagnac, V., Fabre, S., and Berger, G.: $\mathrm{Ca}, \mathrm{Na}, \mathrm{K}$ and $\mathrm{Mg}$ concentrations in seawater by inductively coupled plasma atomic emission spectrometry analyses: applications to IAPSO standard seawater, hydrothermal fluids and synthetic seawater solutions, geostandards and geoanalytical research, 38, 355-362, 2014.

Bonvallot, J., Gay, J. C., and Habert, E.: Atlas de la Nouvelle Calédonie, Nouméa, Marseille, 2012.

Boschetti, T. and Toscani, L.: Springs and streams of the Taro-Ceno Valleys (Northern Apennine, Italy): Reaction path modeling of waters interacting with serpentinized ultramafic rocks, Chem. Geol., 257, 76-91, 2008.

Brazelton, W. J., Schrenk, M. O., Kelley, D. S., and Baross, J. A.: Methane- and sulfur-metabolizing microbial communities dominate the Lost City Hydrothermal Field Ecosystem, Appl. Environ. Microb., 72, 6257-6270, 2006.

Brazelton, W. J., Ludwig, K. A., Sogin, M. L., Andreishcheva, E. N., Kelley, D. S., Shen, C.-C., Edwards, R. L., and Baross, J. A.: Archaea and bacteria with surprising microdiversity show shifts in dominance over 1000-year time scales in hydrothermal chimneys, P. Natl. Acad. Sci. USA, 107, 1612-1617, 2010.
Chardon, D. and Chevillotte, V.: Morphotectonic evolution of the New Caledonia ridge (Pacific Southwest) from postobduction tectonosedimentary record, Tectonophysics, 420, 473-491, 2006.

Chardon, D., Austin, J. A., Cabioch, G., Pelletier, B. S., S., and Sage, F.: Neogene history of the northeastern New Caledonia continental margin from multichannel reflection seismic profiles, C. R. Geosci., 340, 68-73, 2008.

Chavagnac, V., Ceuleneer, G., Monnin, C., Lansac, B., Hoareau, G., and Boulart, C.: Mineralogical assemblages forming at hyperalkaline warm springs hosted on ultramafic rocks: a case study of Oman and Ligurian ophiolites, Geochem. Geophy. Geosy., 14, 2474-2495, 2013a.

Chavagnac, V., Monnin, C., Ceuleneer, G., Boulart, C., and Hoareau, G.: Characterization of hyperalkaline fluids produced by low temperature serpentinization of mantle peridotites in the Oman and Ligurian ophiolites, Geochem. Geophy. Geosy., 14, 2496-2522, 2013b.

Cipolli, F., Gambardella, B., Marini, L., Ottonello, G., and Vetuschi Zuccolini, M.: Geochemistry of high-pH waters from serpentinites of the Gruppo di Voltri (Genova, Italy) and reaction path modeling of $\mathrm{CO}_{2}$ sequestration in serpentinite aquifers, Appl. Geochem., 19, 787-802, 2004.

Cluzel, D., Aitchison, J. C., and Picard, C.: Tectonic accretion and underplating of mafic terranes in the Late Eocene intraoceanic fore-arc of New Caledonia (Southwest Pacific): geodynamic implications, Tectonophysics, 340, 23-59, 2001.

Collot, J. Y., Missegue, F., and Malahoff, A.: Anomalies gravimétriques et structure de la croûte dans la région de la Nouvelle-Calédonie: enracinement des péridotites, in: Contribution à l'étude Géodynamique du Sud-Ouest Pacifique, edited by: Equipe de Géologie-Géophysique ORSTOM Nouméa, Trav. Doc. ORSTOM, 147, 549-564, 1982.

Cox, M. E., Launay, J., and Paris, J.: Geochemistry of low temperature geothermal systems in New Caledonia, in: Pacific Geothermal conference and 4th NZ Geothermal Workshop, 453-459, 1982.

Flamand, B.: Les pentes externes du récif barrière de la GrandeTerre de Nouvelle-Calédonie: morphologie, lithologie, contrôle de la tectonique et de l'eustatisme, Université de Bretagne occidentale, Brest, France, 2006.

Fruh-Green, G. L., Kelley, D. S., Bernasconi, S. M., Karson, J. A., Ludwig, K. A., Butterfield, D. A., Boschi, C., and Proskurowski, G.: 30000 years of hydrothermal activity at the Lost City vent field, Science, 301, 495-498, 2003.

Fujii, N., Arcilla, C. A., Yamakawa, M., Pascua, C., Namiki, K., Sato, T., Shikazono, N., and Alexander, W. R.: Natural Analogue Studies of Bentonite Reaction under Hyperalkaline Conditions: Overview of Ongoing Work at the Zambales Ophiolite, Philippines, Proceedings of the 13th International Conference on Environmental Remediation and Radioactive Waste Management, 2010, Vol 2. Am. Soc. Mechanic. Eng., New York, 41-50, 2010.

Garnier, J.: Voyage autour du monde, La Nouvelle-Calédonie (côte orientale), Plon, Paris, 364 pp., 1871.

Guillon, J. H.: Les massifs péridotitiques de Nouvelle-Calédonie: type d'appareil ultrabasique stratiforme de chaîne récente, 1975.

Harvie, C. E., Moller, N., and Weare, J. H.: The prediction of mineral solubilities in natural waters: the $\mathrm{Na}-\mathrm{K}-\mathrm{Mg}-\mathrm{Ca}-\mathrm{H}-\mathrm{Cl}-$ 
$\mathrm{SO}_{4}-\mathrm{OH}-\mathrm{HCO}_{3}-\mathrm{CO}_{3}-\mathrm{CO}_{2}-\mathrm{H}_{2} \mathrm{O}$ system to high ionic strengths at $25^{\circ} \mathrm{C}$, Geochim. Cosmochim. Ac., 48, 723-751, 1984.

Holm, N. G.: The significance of $\mathrm{Mg}$ in prebiotic geochemistry, Geobiology, 10, 269-279, 2012.

Kelley, D. S., Karson, J. A., Blackman, D. K., Fruh-Green, G. L., Butterfield, D. A., Lilley, M. D., Olson, E. J., Schrenk, M. O., Roe, K. K., Lebon, G. T., and Rivizzigno, P.: An off-axis hydrothermal vent field near the Mid-Atlantic Ridge at $30^{\circ} \mathrm{N}$, Nature, 412, 145-149, 2001.

Kelley, D. S., Karson, J. A., Fruh-Green, G. L., Yoerger, D. R., Shank, T. M., Butterfield, D. A., Hayes, J. M., Schrenk, M. O., Olson, E. J., Proskurowski, G., and Jakuba, M.: A serpentinitehosted ecosystem: the lost city hydrothermal field, Science, 307, 1428-1434, 2005.

Knittel, K. and Boetius, A.: Anaerobic oxidation of methane: progress with an unknown process, Annu. Rev. Microbiol., 63, 311-334, 2009.

Königsberger, E., Königsberger, L.-C., and Gamsjäger, H.: Lowtemperature thermodynamic model for the system $\mathrm{Na}_{2} \mathrm{CO}_{3}$ $\mathrm{MgCO}_{3}-\mathrm{CaCO}_{3}-\mathrm{H}_{2} \mathrm{O}$, Geochim. Cosmochim. Ac., 63, 31053119, 1999.

Krause, S., Liebetrau, V., Gorb, S., Sanchez-Roman, M., McKenzie, J. A., and Treude, T.: Microbial nucleation of Mg-rich dolomite in exopolymeric substances under anoxic modern seawater salinity: new insight into an old enigma, Geology, 40, 587-590, 2012.

Lagabrielle, Y. and Chauvet, A.: The role of extensional tectonics in shaping Cenozoic New-Caledonia, B. Soc. Geol. Fr., 179, 315329, 2008 .

Lagabrielle, Y., Maurizot, P., Lafoy, Y., Cabioch, G., Pelletier, B., Regnier, M., Wabete, I., and Calmant, S.: Post-Eocene extensional tectonics in Southern New Caledonia (SW Pacific): insights from onshore fault analysis and offshore seismic data, Tectonophysics, 403, 1-28, 2005.

Lambert, I. and Clever, H. L.: Alkaline Earth Hydroxides in Water and Aqueous Solutions, IUPAC solubility data series, 52, 220 pp., 1992.

Lang, S. Q., Butterfield, D. A., Schulte, M., Kelley, D. S., and Lilley, M. D.: Elevated concentrations of formate, acetate and dissolved organic carbon found at the Lost City hydrothermal field, Geochim. Cosmochim. Ac., 74, 941-952, 2010.

Launay, J. and Fontes, J. C.: Les sources thermales de Prony (Nouvelle Calédonie) et leurs précipités chimiques, exemple de formation de brucite primaire, Geologie de la France, 1, 83-100, 1985.

Magnier, Y.: Une source thermale sous-marine à Prony: le récif de l'aiguille, Rossiniana, 3, 16-17, 1979.

Maurizot, P. and Vendé-Leclerc, M.: Carte géologique de la Nouvelle-Calédonie au 1/500 000, Direction de l'Industrie, des Mines et de l'Energie, Service de la Géologie de NouvelleCalédonie, Bureau de Recherches Géologiques et Minières, Nouméa, 2009.

Millero, F. J.: Chemical oceanography, in: Marine Sciences series, third edition, edited by: Kennish, M. K., CRC Taylor and Francis, p. 496., 2006.

Monnin, C. and Hoareau, G.: Chemical equilibrium between aqueous fluids and minerals in the marine environment, in: Ionpartitioning in ambient temperature aqueous systems, edited by: Prieto, M. and Stoll, H., European Mineralogical Union, 227257, 2010.
Monnin, C., Pelletier, B., Boulart, C., and Quéméneur, M.: Suivi temporel de la température et de la composition des eaux et des gaz des sources hyperalcalines de la Baie de Prony (NouvelleCalédonie), Grand Observatoire de l'Environnement et de la Biodoversité (GOPS), Nouméa, Nouvelle Calédonie, unpublished report, 2013.

Morrill, P. L., Kuenen, J. G., Johnson, O. J., Suzuki, S., Rietze, A., Sessions, A. L., Fogel, M. L., and Nealson, K. H.: Geochemistry and geobiology of a present-day serpentinization site in California: the Cedars, Geochim. Cosmochim. Ac., 109, 222-240, 2013.

Morse, J. W., Arvidson, R. S., and Luttge, A.: Calcium carbonate formation and dissolution, Chem. Rev., 107, 342-381, 2007.

Mottl, M. J.: Higest pH?, available at: http://www.geochemsoc. org/publications/geochemicalnews/gn141 oct09/highestph.htm, 2009.

Mottl, M. J., Wheat, C. G., Fryer, P., Gharib, J., and Martin, J. B.: Chemistry of springs across the Mariana forearc shows progressive devolatilization of the subducting plate, Geochim. Cosmochim. Ac., 68, 4915-4933, 2004.

Muntener, O.: Serpentine and serpentinization: a link between planet formation and life, Geology, 38, 959-960, 2010.

Neal, C. and Stanger, G.: Calcium and magnesium-hydroxide precipitation from alkaline groundwaters in Oman, and their significance to the process of serpentinization, Mineral. Mag., 48, 237-241, 1984a.

Neal, C. and Stanger, G.: Past and present serpentinization of ultramafic rocks; an example from the Semail ophiolite nappe of Northern Oman, in: Proceedings of the NATO Advanced Research Workshop on the The Chemistry of Weathering, edited by: Drever, T., Reidel Publishing Company, 249-275, 1984b.

Neal, C. and Shand, P.: Spring and surface water quality of the Cyprus ophiolites, Hydrol. Earth Syst. Sci., 6, 797-817, doi:10.5194/hess-6-797-2002, 2002.

Ouillon, S., Douillet, P., Lefebvre, J. P., Le Gendre, R., Jouon, A., Bonneton, P., Fernandez, J. M., Chevillon, C., Magand, O., Lefevre, J., Le Hir, P., Laganier, R., Dumas, F., Marchesiello, P., Belmadani, A., Andrefouet, S., Panche, J. Y., and Fichez, R.: Circulation and suspended sediment transport in a coral reef lagoon: the south-west lagoon of New Caledonia, Mar. Pollut. Bull., 61, 269-296, 2010.

Pelletier, B. and Chevillon, C.: Morphologies sous marines particulières et constructions chimiques et biologiques dans le lagon sud-ouest de Nouvelle-Calédonie: les aiguilles hydrothermales de la baie du Prony et les monticules d'huîtres du banc Gail, Abstract book, Congrès Biodec, Nouméa (New Caledonia), 84-85, 2006.

Pelletier, B., Chevillon, C., Menou, J.L., Butscher, J., Folcher, E., Geoffray, C., Bore, J. M., Panché, J. Y., and Perrier, J.: Plongées, forage et cartographie Baie du Prony et Banc Gail, lagon Sud de Nouvelle-Calédonie, NO, ALIS, 13-17 Juin 2004 et cartographie baie du Prony NO, ALIS, 25-26 Septembre 2005, 2006.

Perner, M., Hansen, M., Seifert, R., Strauss, H., Koschinsky, A., and Petersen, S.: Linking geology, fluid chemistry, and microbial activity of basalt- and ultramafic-hosted deep-sea hydrothermal vent environments, Geobiology, 11, 340-355, 2013.

Pirard, C., Hermann, J., and O'Neill, H. S.: Petrology and geochemistry of the crust-mantle boundary in a nascent arc, Massif du Sud Ophiolite, New Caledonia, SW Pacific, J. Petrol., 54, 1759-1792, 2013. 
Pisapia, C. and the HYDROPRONY scientific team: The alkaline hydrothermal field of the Prony Bay, New Caledonia, in: Serpentine Days workshop, Porquerolles, France, 2012.

Pisapia, C., Gerard, E., Gerard, M., and Menez, B.: Organomineralization drives early chimney edification at the hyperalkaline hydrothermal field of the Prony Bay (New Caledonia), Goldschmidt Conference, Florence (Italy), Mineral. Mag., 2013.

Pisapia, C., Gérard, E., Gérard, M., Erauso, G., Postec, A., Monnin, C., Payri, C., Pelletier, B., and Ménez, B.: Organomineralization drives early chimney edification at the hyperalkaline hydrothermal field of the Prony Bay (New Caledonia), P. Natl. Acad. Sci. USA, in preparation, 2014.

Postec, A., Quéméneur, M., Bes, M., Mei, N., Benaissa , F., Payri, C., Pelletier, B., Monnin, C., Dombrowsky, L., Ollivier, B., Gérard, E., Pisapia, C., Gérard, M., Ménez, B., and Erauso, G.: Microbial communities in a serpentinite-hosted ecosystem: the Prony hydrothermal field, New Caledonia, PLOS ONE, submitted, 2014.

Power, I. M., Wilson, S. A., Thom, J. M., Dipple, G. M., and Southam, G.: Biologically induced mineralization of dypingite by cyanobacteria from an alkaline wetland near Atlin, British Columbia, Canada, Geochem. T., 8, doi:10.1186/1467-4866-813, 2007.

Prokurovski, G.: Abiogenic hydrocarbon production at the biosphere-geosphere interface via serpentinization reactions, in: Hanbook of Hydrocarbon and Lipid Micobiology, edited by: Timmis, K. N., Springer, 216-231, 2010.

Quéméneur, M., Bes, M., Postec, A., Meil, N., Hamelin, J., Monnin, C., Chavagnac, V., Payri, C., Pelletier, B., Donbrowski, L., Gérard, M., Pisapia, C., Gérard, E., Ménez, B., Ollivier, B., and Erauso, G.,: Spatial distribution of microbial communities in the shallow submarine alkaline hydrothermal field of the Prony Bay, New Caledonia, Environ. Microbiol., doi:10.1111/17582229.12184, 2014.

Quesnel, B., Gautier, P., Boulvais, P., Cathelineau, M., Maurizot, P., Cluzel, D., Ulrich, M., Guillot, S., Lesimple, S., and Couteau, C.: Syn-tectonic, meteoric water-derived carbonation of the New Caledonia peridotite nappe, Geology, 41, 1063-1066, 2013.

Rinder, T., Dietzel, M., and Leis, A.: Calcium carbonate scaling under alkaline conditions - case studies and hydrochemical modelling, Appl. Geochem., 35, 132-141, 2013.
Roberts, J. A., Kenward, P. A., Fowle, D. A., Goldstein, R. H., Gonzalez, L. A., and Moore, D. S.: Surface chemistry allows for abiotic precipitation of dolomite at low temperature, P. Natl. Acad. Sci. USA, 110, 14540-14545, 2013.

Russell, M. J.: The alkaline solution to the emergence of life: energy, entropy and early evolution, Acta Biotheor., 55, 133-179, 2007.

Russell, M. J., Hall, A. J., and Martin, W.: Serpentinization as a source of energy at the origin of life, Geobiology, 8, 355-371, 2010.

Sader, J. A., Leybourne, M. I., McClenaghan, B., and Hamilton, M. S.: Low-temperature serpentinization processes and kimberlite groundwater signatures in the Kirkland Lake and Lake Timiskiming kimberlite fields, Ontario, Canada: implications for diamond exploration, Geochemistry-Explor. Env. A., 7, 3-21, 2007.

Schrenk, M. O., Kelley, D. S., Bolton, S. A., and Baross, J. A.: Low archaeal diversity linked to subseafloor geochemical processes at the Lost City Hydrothermal Field, Mid-Atlantic Ridge, Environ Microbiol., 6, 1086-1095, 2004.

Stanger, G.: The Hydrology of the Oman Mountains, Ph.D. thesis, The Open University, UK, 1985.

Szponar, N., Brazelton, W. J., Schrenk, M. O., Bower, D. M., Steele, A., and Morrill, P. L.: Geochemistry of a continental site of serpentinization, the Tablelands Ophiolite, Gros Morne National Park: A Mars analogue, Icarus, 224, 286-296, 2012.

Toner, B. M., Lesniewski, R. A., Marlow, J. J., Briscoe, L. J., Santelli, C. M., Bach, W., Orcutt, B. N., and Edwards, K. J.: Mineralogy drives bacterial biogeography of hydrothermally inactive seafloor sulfide deposits, Geomicrobiol. J., 30, 313-326, 2013.

Xiong, Y. L.: Thermodynamic properties of brucite determined by solubility studies and their significance to nuclear waste isolation, Aquat. Geochem., 14, 223-238, 2008.

Xu, J., Yan, C., Zhang, F. F., Konishi, H., Xu, H. F., and Teng, H. H.: Testing the cation-hydration effect on the crystallization of $\mathrm{Ca}-$ $\mathrm{Mg}-\mathrm{CO}_{3}$ systems, P. Natl. Acad. Sci. USA, 110, 17750-17755, 2013. 